\title{
Okul Öncesi Öğretmenlerinin Fen Eğitiminin İçeriği ve Standartlarına İlişkin Görüşlerinin İncelenmesi
}

DOI: 10.26466/opus.631378

*

\author{
Hatice Dağlı * - H. Elif Dağlığlu ** \\ * Dr. Öğr. Üyesi, Kahramanmaraş Sütçü İmam Üniv., Eğitim Fakültesi, Kahramanmaraş/ Türkiye \\ E-Posta: hnddagli@hotmail.com \\ ORCID: 0000-0002-0788-0413 \\ ** Prof. Dr., Gazi Üniversitesi, Eğitim Fakültesi, Ankara/ Türkiye \\ E-Posta: edaglioglu1@gmail.com \\ ORCID: 0000-0002-7420-815X
}

\section{Öz}

Bu araştırmada, okul öncesi eğitim kurumlarında uygulanan fen eğitiminin içeriği konusunda öğretmen görüşlerinin incelenmesi amaçlanmıştır. Bununla birlikte okul öncesi dönemde fen eğitimi uygulamaları konusunda mevcut durum belirlenmeye çalışılmıştır. Araştırmanın çalışma grubunu Sivas il merkezinde bulunan Milli Eğitim Bakanlı̆̆ı'na bağlı ilkokulların anasınıfları ve bağımsız anaokulları ile Aile, Çalışma ve Sosyal Hizmetler Bakanlığı'na bağlı gündüz bakımevlerinde 36-72 aylık çocuklarla çalışan 150 öğretmen oluşturmuştur. Araştırma nitel araştırma yöntemlerinden durum çalışması deseni kullanılarak gerçekleştirilmiştir. Araştırmanın amacına ulaşabilmek için 'Okul Öncesi Dönemde Fen Eğitiminin İçeriğgine İlişkin Öğretmen Görüşleri Görüşme Formu' geliştirilmiştir. Toplanan veriler içerik analizi kullanılarak incelenmiştir. Verilere ilişkin betimsel istatistikler yapılmış; maddelerin frekans ve yüzde değerleri hesaplanmıştır. Araştırma sonucunda öğretmenlerin \%78.9'u fen eğitimi standartlarının olması konusunda olumlu görüşe sahipken \%7.5'i standartların olmaması gerektiğini bildirmiştir. Olumlu görüsş belirten öğretmenler eğitim programında 'fen eğitimi içerik standartlarının' yer almasının çocukların yaş ve gelişim özelliklerine uygun etkinliklerin planlanmasın ve fen eğitimin kademeli olarak ilerlemesini să̆layarak çocuklara farklı içeriklerle ilgili öğrenme yaşantıları oluşturacağını ifade ederken; olumsuz görüşe sahip öğretmenlerin eğitim programı, uygulama, eğitim ortamının düzenlenmesi noktasında standartlarla ilgili kaygıları olduğu görülmektedir.

Anahtar Kelimeler: Okul öncesi eğitim, fen eğitimi, içerik standartları, yaşam bilimi, fizik bilimi, dünya ve uzay bilimi

*Bu çalışma ilk yazarın yüksek lisans tezinden üretilmiştir. 


\title{
An Analysis of Preschool Teachers' Opinions on the Content and Standards of Science Education
}

\begin{abstract}
In this study, teacher opinions on the content of science education at pre-school educational institutions are aimed to be analyzed. In addition to this, the current situation with regard to the applications of science education at pre-school level has been attempted to be identified. Target population of the study consisted of 150 teachers who worked with 36 to 72-month children at the primary school preschool classes and kindergartens affiliated to the Ministry of National Education and the day care centers affiliated to T. C. Minister of Family, Labour and Social Services, in Sivas province. The research has been carried out using case study design, one of the qualitative research method. A 'Teacher Opinions Interview Form on the Content of Pre-School Science Education' has been developed the purpose of the research. Content analysis performed by researcher, descriptive statistics were produced for the data and the frequency and percent values of matters were calculated. In conclusion $\% 78.9$ of teachers expressed positive opinion and \%7.5 reported negative opinion about science standards. In line with the data obtained from the research, teachers who expressed positive opinions, it is considered that involvement of 'content standards for science education' in the curriculum would assist teachers in leading science activities, enable planning classroom activities appropriate for the age and development characteristics of children and create learning experiences for children on different subjects/concepts, by ensuring gradual improvement of science education. The results showed that teachers who expressed negative opinions have some worries about education programme, practicing, classroom environment.
\end{abstract}

Keywords: Pre-school education, science education, content standards, life science, physics, earth and space science,

*Bu çalışma ilk yazarın yüksek lisans tezinden üretilmiştir. 


\section{Giriş}

Çocukların öğrenme isteklerinin nitelikli okul deneyimleriyle ilk olarak bir araya geldiği dönem okul öncesi eğitim sürecidir (Dickinson ve Porche, 2011; Günindi, 2012). Okul öncesi eğitimin amacl, çocuklara uygun içerik ve eğitim programları ile farklı öğrenme ortamları oluşturmak, çocukların bilgiyi yapılandırmasını, bilimsel düşünebilme ve problem çözme becerileri kazanmasını, kendisini ve sosyal toplumdaki yerini anlamasını sağlamaktır (Pennsylvania Department of Education [PDE], 2009).

Okul öncesi dönemde çocukların aktif olarak yaşadıkları deneyimler, keşif yapmalarını ve çevrelerindeki dünyayı anlamlandırmalarını sağlar. Çocukların yaşadıkları bu deneyimler soyut ve bilimsel düşüncenin temelini oluşturur. Deney yapmasına, veri toplamasına ve sonuca ulaşmasına firsat sağlanan çocukların bilimsel süreç becerileri ve doğal dünya hakkındaki görüşleri gelişir (Campbell ve Jobling, 2012; PDE, 2009; Skamp, 2011). Çocuklar duyular yoluyla ve yaparak-yaşayarak bilimsel tecrübeler kazanabilirler. Çocukların okul öncesi eğitim ortamlarında bilimsel tecrübe kazanabileceği en temel etkinliklerden bir tanesi fen etkinlikleridir. Okul öncesi dönemde fen eğitiminin amacı çocuklara soru sorma, gözlem, araştırma, inceleme ve keşfetme becerileri kazandırarak (MEB, 2013); çevresinde gelişen olayları yorumlamasını ve bilimsel süreç becerilerini kullanabilmesini sağlamaktır (Kandır, Özbey ve İnal, 2010; Yılmaz, 2010). Bu süreçte etkili bir öğrenme için uygun düzenlenmiş fiziksel ortam büyük önem taşımaktadır (Kandır, Can Yaşar, İnal, Yazıcı, Uyanık ve Uyanık Balat, 2012). Sınıf ortamında yer alan fen merkezinin çocukların araştırma yapmalarına imkan tanıyacak şekilde, çocuğa kazandırılması hedeflenen bilgi ve becerileri yansıtan materyal ve ekipmanlar içeren, fiziksel olarak çeşitli uyaranlarla zenginleştirilmiş, değiştirilebilir özelliklere sahip olması beklenir (Brunton ve Thornton, 2010; Genç Kumtepe, 2011). Fen merkezinde verilen içeriğe uygun şekilde yer alan her bir materyal çocuğun öğrenmesini kolaylaştıracaktır.

Birçok fen kavramı karmaşıktır ve bunun çocuklara nasıl aktarılması gerektiğiyle ilgili zorluklar yaşanmaktadır. Öğretmenlerin çocukların etkili öğrenmesini sağlayabilmesi için temel bilimsel kavramlara yer vermesi gerekmektedir. Bilimsel kavramları anlamak fen eğitimi programının önemli bir parçasıdır (National Science Education Standarts [NSES],1996). Okul öncesi 
dönemde çocukların, evde ve okul ortamında temel bilim becerilerini ve bilimsel anlayışlarını geliştirmek için nitelikli fen etkinliklerine ihtiyaçları vardir (Gropen Kook, Hoisington ve Clark-Chiarelli, 2017; Piasta, Pelatti ve Miller, 2015). Fen kavramların anlamak bilimsel düşünme becerilerini de beraberinde getirir. Erken yaşlarda çocukların fikirlerini açıklaması bilimsel düşüncenin gelişimi için çok önemlidir. Çocuklar araştırmalarla, problem çözerek ya da tartışmalarla fikirlerini açıklar ve varsayımlarını ifade edip olaylar arasında bağlantı kurarlar (Johnston, 2005, s.79). Neden-sonuç ilişkisi kurarak, farklı sonuçlar elde ederler (Brunton ve Thornton, 2010:12). Bu bağlamda okul öncesi dönemde fen eğitiminde yer verilen içerik ve bilimsel süreç becerileri, sınıf ortamlarında yer alan çeşitli materyaller, öğretmenlerin sahip oldukları nitelikler, fen eğitimine gösterdikleri tutumlar ve okul öncesi dönemde fen eğitiminin içeriği konusunda programın uygulayıcısı olarak öğretmenlerin bakış açları fen eğitiminin niteliğini önemli ölçüde etkilemektedir (Babaroğlu ve Okur Metwalley, 2018; Doğan ve Simsar, 2018; Ültay, Ültay ve Çilingir, 2018). Okul öncesi öğretmenlerinin fen eğitimi konusunda kendilerini geliştirmeleri, öğretmenlerin yeni edindikleri bilgi ve becerileri uygulamaya dönüştürme becerisine bağlı olarak çocukların daha sık aralıklarla fen etkinlikleriyle karşılaşmalarını sağlar (Burke ve Hutchins 2016).

Yapılan araştırmalar öğretmenlerin içerik bilgisi ile pedagojik süreç ve yöntem-teknik bakımından uygulama konusunda ciddi bir gelişime ihtiyacı olduğunu göstermektedir (Ayvacı vd., 2002; Güler ve Bıkmaz, 2002; Kallery ve Psilos, 2002; Olgan, 2015; Tsitouridou,1999). Oysaki çocuğun bilimsel kavramları algılamasına ilişkin gelişimi ve çocukların gelişim süreci düşünüldügünde, erken çocukluk döneminde fen büyük önem taşımaktadır. Çünkü çocuklar için fenin amacı etraflarındaki dünyayı anlamalarını ve fark etmelerini sağlamaktır (Tu ve Hsiao, 2008, s.1). Günümüzde genel yaklaşıma göre, fen çalışmalarının okul öncesi eğitim sınıflarında başlaması gerekmektedir (Kallery ve Psillos, 2002, s.49-61). Leibham, Alexander ve Johnson (2013) erken eğitimde yer verilecek fen kavramlarının çocukların ileride fene dair başarısinda önemli bir etken olduğunu belirtmişlerdir.

Son dönemlerde fen etkinlikleri okul öncesi eğitim programlarında önemli düzeyde yer almaya başlamış ve çocukların fen kavramlarını öğrenirken sınıf içerisinde aktif katılımlarının sağlanması ve kendi bilimsel süreç becerilerini geliştirmelerinin önemi üzerinde durulmaktadır (NRC, 2012). Amerika Bilim İlerleme Kurumu (AAAS) ve Amerika Ulusal Araştırma Konseyi 
(NRC) fen eğitiminin gelişimi ve öğretimiyle ilgili çalışmalarında daha az kavramın derinlemesine öğretiminin daha çok kavramın yüzeysel öğretiminden daha iyi olacağı vurgusunu yapmış (NSES, 1996) ve bu bağlamda Ulusal Bilim Eğitimi Standartları oluşturulmuştur. Yapılan çalışmalar da bilim programının çocukların kavramsal algılarında farklılıklar yarattığını ve bilim programının fen eğitiminde önemli olduğunu ve çocuklar üzerinde olumlu etkiler yarattı̆̆ını göstermiştir (Alabay, 2010, s.70-79; Hatch, 2005; Sarıtaş, 2010; Tao, Oliver ve Venville, 2012). Fen eğitim programına ilişkin standartlarda farklı yaş grubundaki çocukların öğrenmesi ve bilmesi gereken kavramlar sınırlandırılmıştır. Standartlar bütün çocukların başarabileceği şekilde tasarlanmış ve onların aktif bir şekilde katılımını sağlayan bir süreç olarak ifade edilmiştir (Ansberry ve Morgan, 2007, s.35). Standartlar çocukların ne yapmaları ya da neyi bilmeleri gerektiği ile ilgili bilgi vermektedir (PDE, 2009). Amerika'da birçok eyalette, İskoçya'da, İrlanda da ve birçok bölgede fen eğitimine dair standartların yer aldığı ve bu standartların dünya ve uzay bilimi, yaşam bilimi, fizik bilimi ve bilimsel süreç becerileri üzerinde yoğunlaştığı görülmektedir.

Fen eğitimi açısından Türkiye'deki gelişmelere bakıldığında karşımıza MEB 2013 Okul Öncesi Eğitim Programı çıkmaktadır. Bu programda temel yaklaşım olarak fen etkinliklerine yer verilmiş, özellikle eğitim sürecinde kazanım ve göstergelerin kazandırılmasında konu veya tema merkezli eğitimin söz konusu olmadığı vurgulanmıştır. Eğitim süreci planlanırken çeşitli konulardan yararlanılabileceği, fakat asıl amacın ele alınan konunun öğretimi değil o konu yardımı ile kazanım ve göstergelerin gerçekleştirilmesi olduğu ifade edilmiştir (MEB, 2013). Bir başka deyişle okul öncesi eğitim programında fen eğitimine ilişkin içeriğe dair ulusal standartlar yoktur. Programda yer alan kavram listesi incelendiğinde renk, şekil, boyut, miktar, yön, sayılar, duyular, duygular, zit kavramlar ve zaman kavramları ele alınarak kavramlar belirli kategorilerde toplanmış fakat bu kavramların yaş gruplarına uygunluğu, etkinlik alanları vb. kategoriler oluşturulmamıştır.

Eğitim standartlarına yönelik uygulamalar göz önünde bulundurulduğunda Türkiye'de okul öncesi eğitim programında çocukların gelişim özelliklerinin gelişim alanlarına göre 36-48, 48-60 ve 60-72 aylık çocuklar için ayrı ayrı belirtildiği ancak, okul öncesi dönemde yer verilebilecek kavramların yaş grubuna göre ayrı ayrı ele alınmadığı görülmektedir. İncikabı ve Tuna (2012) Türkiye okul öncesi programının gelişimsel özelliklere ait kazanımlardan 
oluştuğunu, eğitim standartlarının ise süreç ve içerik odaklı olup öğrenme alanlarına yönelik kazanımlar içerdiğini ifade etmişlerdir. Öçal (2017) Amerika'daki ortak temel eyalet standartları ile MEB Okul Öncesi Eğitim Programını matematik bağlamında karşılaştırdığı çalışmasında okul öncesi eğitimi seviyesinde benzerlik ve farklılıklar olduğunu belirtmiştir. Taştepe (2012), erken çocukluk dönemi fen ve matematik eğitimi içerik standartları değerlendirme araçlarını geliştirmiş ancak, bu süreçte yer verilebilecek standartlar konusunda ele alınması gereken içeriğe değinmemiştir. Diğer yandan Okul öncesi dönemde çocuğa uygulanacak fen eğitiminin öneminden yola çıkarak, Amerika Birleşik Devletleri Ulusal Araştırma Konseyi (NRC), okul öncesi dönemde çocuğa uygulanan fen eğitiminin içerik standartlarını "Bilimde Birleştirici Kavramlar ve Süreçler, Bilimsel Sorgulama, Fiziksel Bilim, Yaşam Bilimi, Dünya ve Uzay Bilimi, Bilim ve Teknoloji, Kişisel ve Sosyal Açıdan Bilim, Bilimin Doğası ve Tarihi" olarak belirlemiş ve bunu yaş gruplarına göre uyarlamıştır (NRC, 2012).

Elde edilen bu bilgilerden yola çıarak söz konusu araştırmada okul öncesi eğitim kurumlarında uygulanan fen eğitiminin içeriği konusunda öğretmen görüşlerinin incelenmesini amaçlamıştır. Bu bağlamda okul öncesi eğitim kurumlarında öğretmenlerin fen eğitimine yer verme sıklığı ve kullandıkları yöntem-teknikler, uygulanan fen eğitiminin içeriği konusundaki görüşleri, fen eğitiminde yer verilebilecek dünya ve uzay bilimi, yaşam bilimi ve fizik bilimi ile ilgili konu/kavramları kullanma durumları ve kullanma sıklıklarl, fen eğitiminde yer verilebilecek bilimsel süreç becerilerini kullanma durumları ve sıklıkları, fen eğitimine ilişkin içeriğin ne ölçüde çocuklara sunulduğu ve bu süreçte eğitim standartlarına ilişkin görüşleri irdelenmiştir.Okul öncesi dönemde yaş ve gelişim özelliklerinin farklı olduğu ve eğitim programında çocuk merkezli bir yaklaşımın benimdendiği göz önünde bulundurulduğunda, bu araştırma okul öncesi dönem fen eğitimi uygulamalarında yer verilen içeriklerin, bilimsel süreç becerilerinin, yöntem ve tekniklerin belirlenmesi, okul öncesi fen eğitimi konusunda öğretmen görüşlerinin ortaya çıkarılması açısından önemlidir. 


\section{Yöntem}

\section{Araştırmanın Modeli}

Araştırmanın amacı doğrultusunda bu çalışmada nitel araştırma yöntemlerinden olan durum çalışması yöntemi benimsenmiştir. Durum çalışmalarında belirli bir duruma ilişkin etkenler bütüncül bir yaklaşımla incelenerek ilgili duruma ilişkin sonuçlar ortaya koymak amaçlanır (Yıldırım ve Şimşek, 2013). Bu doğrultuda elde edilen veriler frekans ve yüzde değerleri üzerinden değerlendirilmiştir.

\section{Çalışma Grubu}

Araştırmanın evrenini Sivas il merkezinde bulunan Milli Eğitim Bakanlığı'na bağlı ilköğretim okullarının anasınıfları ve bağımsız anaokullarında ve Aile, Çalışma ve Sosyal Hizmetler Bakanlığı'na (ASHB) bağlı gündüz bakımevlerinde 36-72 aylık çocuklarla çalışan öğretmenler oluşturmuştur. Çalışma grubu İl Milli Eğitim Müdürlüğü ve Sivas Aile, Çalışma ve Sosyal Hizmetler İl Müdürlüğü'nden elde edilen veriler doğrultusunda belirlenmiş ve \%95 güvenirlik ve \%8 duyarlılıkla toplam 150 öğretmen ile görüşülmüştür.

Araştırmanın örneklemini oluşturan öğretmenlerin bazı demografik ve mesleki özelliklerine göre dağılımına Tablo 1'de yer verilmiştir.

Tablo 1. Öğretmenlerin demografik ve mesleki özelliklere göre dağılımı

\begin{tabular}{|c|c|c|c|}
\hline & & $\mathbf{n}$ & $\%$ \\
\hline \multirow{3}{*}{ Cinsiyet } & Kadın & 146 & 97.3 \\
\hline & Erkek & 4 & 2.7 \\
\hline & Toplam & 150 & 100 \\
\hline \multirow{5}{*}{$\begin{array}{l}\text { Mezun } \\
\text { Olunan } \\
\text { Okul Türü }\end{array}$} & Kız Meslek Lisesi & 20 & 13.5 \\
\hline & Meslek Yüksek Okulu & 5 & 3.4 \\
\hline & Lisans (Okul öncesi öğretmenliği) & 108 & 73.0 \\
\hline & Lisans (Çocuk Gelişimi) & 15 & 10.1 \\
\hline & Toplam & 148 & 100 \\
\hline \multirow{4}{*}{ Hizmet yılı } & 5 ve daha az & 102 & 69.4 \\
\hline & 6-9 yil & 24 & 16.3 \\
\hline & 10 yıl ve üzeri & 21 & 14.3 \\
\hline & Toplam & 147 & 100 \\
\hline \multirow{4}{*}{$\begin{array}{l}\text { Görev Yapılan } \\
\text { Okul Türü }\end{array}$} & Resmi Bağımsız Anaokulu & 43 & 28.7 \\
\hline & ASHB'ye bağlı gündüz bakımevi & 17 & 11.3 \\
\hline & Resmi İlköğretim okuluna bağlı anasınıfı & 90 & 60.0 \\
\hline & Toplam & 150 & 100 \\
\hline
\end{tabular}


Tablo 1'de öğretmenlerin \%97.3'ü (n=146) kadın, \%2.7'si (n=4) erkektir. Mezun olunan okul türüne göre öğretmenlerin \%13.5'i (n=20) kız meslek lisesi, \%3.4'ü (n=5) meslek yüksek okulu, \%73.0'ü (n=108) okul öncesi öğretmenliği lisans mezunu ve geri kalan \%10.1'i $(n=15)$ çocuk gelişimi lisans mezunu olduğu görülmektedir. Öğretmenlerin \%69.4'ü (n=120) 5 ve daha az, \%16.3'ü (n=24) 6-9 yıl, \%14.3'ü (n=21) 10 yıl ve üzeri hizmet yınına sahiptir. Öğretmenlerin görev yaptıkları okul türü incelendiğinde \%28.7'si $(n=43)$ resmi bağımsız anaokulu, \%13.3'ü ( $n=17)$ ASHB'ye bağlı gündüz bakımevi, \%60'1 (n=90) resmi ilköğretim okuluna bağlı anasınıfında çalışmaktadır.

\section{Veri Toplama Araçlan}

Veri toplama sürecinde araştırmacılar tarafından geliştirilen ve okul öncesi eğitim kurumlarında uygulanan fen eğitiminin içeriği konusunda öğretmen görüşlerini belirlemek amacıyla hazırlanan 'Okul Öncesi Dönemde Fen Eğitiminin İçeriğine İlişkin Öğretmen Görüşleri Görüşme Formu' kullanılmıştir.

\section{Okul Öncesi Dönemde Fen Eğitiminin İçeriğine İlişkin Öğretmen Görüşleri}

Görüşme Formu: Araştırmada öğretmenler hakkında ve verilen fen eğitimi konusunda bilgiler toplayabilmek amacıyla araştırmacı tarafından ‘Okul Öncesi Dönemde Fen Eğitiminin İçeriğine İlişkin Öğretmen Görüşleri Görüşme Formu' kullanılmıştır.

Bu form iki bölümden oluşmaktadır. İlk bölümde öğretmenlerin mezun oldukları okul türü, hizmet yılı gibi özelliklerine ilişkin bilgilere yer verilmiştir. İkinci bölümde öğretmenlerin sınıf içi uygulamaları ve okul öncesi dönemde fen eğitiminde yer alması düşünülen kavramlara ilişkin görüşlerini belirttikleri, hem açık uçlu hem de seçmeli soruların olduğu yarı yapılandırılmış olarak hazırlanan sorular bulunmaktadır. 'Okul Öncesi Dönemde Fen Eğitiminin İçeriğine İlişkin Öğretmen Görüşleri Görüşme Formu' hazırlanmadan önce gerekli literatür taraması yapılmış; mevcut yurt içi ve yurt dışı okul öncesi dönemde fen eğitiminde yer verilen içerikler incelenmiş ve problem durumu belirlenmiş, bulgular doğrultusunda farklı üniversitelerden alanında uzman on üç öğretim üyesinin uzman görüşleri alınarak okul öncesi fen eğitiminde yer verilebilecek içerik belirlenmiştir. Görüşme formundaki 
maddelerin araştırma sorularına cevap verip vermediğini anlamak için $26 \mathrm{ki}$ şilik okul öncesi eğitimi öğretmeniyle pilot uygulama çalışması yapılmış ve araştırma sorularının anlaşılır olduğu test edildikten sonra gerekli düzeltmeler yapılarak uygulamaya hazır hale getirilmiştir.

\section{Veri Analizi}

Toplanan verilerin içerik analizi araştırmacılar tarafından yapılmıştır. Bu çalışmada, betimsel içerik analizi yöntemlerinden biri olarak kategorik çözümleme tekniği kullanılmıştır. Kategorik çözümleme bir mesajın birimlere bölünerek önceden saptanmış veya inceleme sırasında eklenen ölçütlere göre kategoriler halinde gruplandırılmasıdır (Tavşancl ve Aslan, 2001). Yapılan içerik analizi doğrultusunda maddelerin frekans ve yüzde değerleri hesaplanmıştır. Bu doğrultuda açık uçlu sorulara öğretmenler tarafından verilen cevaplar incelenmiş; öğretim ilke ve yöntemleri boyutu çocuğa uygunluk, basitten karmaşığa, yaşama yakınlık, somuttan soyuta, aktif katılım ilkelerine göre; eğitim ortamı boyutu fiziksel ortam ve eğitsel ortam olarak; eğitim programı açısından hazırlık (ihtiyaca göre eğitim, öğretmene rehber olma), uygulama (kolaylık, düzen, bilimsel süreç becerileri, yöntem-teknik), değerlendirme (amaç kazanımlara ulaşma, ölçülebilir olma, kalıcı olma, kaliteli olma, verimli olma) olarak kodlanmış, kodlar aralarındaki benzerlik ve farklılıklara göre kategoriler oluşturulmuş ve üç alan uzmanından görüş alınarak analiz gerçekleştirilmiştir. Öğretmenlerin okul öncesi eğitim sürecinde yapılması gereken fen eğitimine yönelik (Tablo 8) ve fen eğitimi standartlarının olumlu ve olumsuz yönlerine (Tablo 10 ve11) ilişkin görüşlerini belirtirken birden fazla görüş belirtmeleri sebebiyle belirtilen ifadelerin sayısı dikkate alınarak analiz yapılmıştır.

\section{Bulgular}

Okul öncesi eğitim kurumlarında öğretmenlerin uyguladığı fen eğitimi ve bu eğitime yer verme sıklıkları, kullandıkları yöntem ve teknikler, fen etkinlikleri kapsamında yaptıkları etkinlikler ve fen eğitimi standartları hakkındaki görüşleri incelenmiş ve elde edilen bulgular tablolar halinde ele alınmıştır.

Tablo 2' de çocukların yaş gruplarına göre öğretmenlerin fen eğitimine yer verme sıklığına ilişkin dağılım yer almaktadır. 
Tablo 2. Çocukların yaş gruplarına göre öğretmenlerin fen eğitimine yer verme sıklığına ilişkin dă̆ılım

\begin{tabular}{|c|c|c|c|c|c|c|c|c|c|}
\hline & & \multicolumn{8}{|c|}{ Öğretmenin çalıştığı yaş grubu } \\
\hline & & \multicolumn{2}{|c|}{$36-48$ ay } & \multicolumn{2}{|c|}{$48-60$ ay } & \multicolumn{2}{|c|}{$60-72$ ay } & \multicolumn{2}{|c|}{ Toplam } \\
\hline & & $\mathbf{n}$ & $\%$ & $\mathbf{n}$ & $\%$ & $\mathbf{n}$ & $\%$ & n & $\%$ \\
\hline \multirow{4}{*}{$\begin{array}{l}\text { Fen Eğitimine } \\
\text { Yer Verme Sıklığı }\end{array}$} & Haftada bir-iki kez & 7 & 70.0 & 8 & 42.1 & 70 & 57.9 & 85 & 56.7 \\
\hline & Haftada üç-dört kez & 0 & 0 & 3 & 15.8 & 12 & 9.9 & 15 & 10.0 \\
\hline & İki-üç haftada bir & 3 & 30.0 & 8 & 42.1 & 39 & 32.2 & 50 & 33.3 \\
\hline & Toplam & 10 & 100 & 19 & 100 & 121 & 100 & 150 & 100 \\
\hline
\end{tabular}

Tablo 2'de çocukların yaş gruplarına göre öğretmenlerin fen eğitimine yer verme sıklığına ilişkin dağılım incelendiğinde 36-48 ay grubunda görev yapan öğretmenlerin \%70.0'i (n=7) haftada bir-iki kez, \%30.0'u (n=3) iki üç haftada bir fen eğitimine yer verdiklerini belirtmişledir. 48-60 ay grubunda görev yapan öğretmenlere bakıldığında, öğretmenlerin \%42.1'i $(n=8)$ haftada bir-iki kez, \%15.8'i (n=3) haftada üç-dört kez, \%42.1'i (n=8) iki üç haftada bir fen eğitimine yer verdiklerini ifade etmişlerdir. 60-72 ay grubunda görev yapan öğretmenlerin $\% 57.9^{\prime} \mathrm{u}(\mathrm{n}=70)$ haftada bir-iki kez, \%9.9'u $(\mathrm{n}=12)$ haftada üç-dört kez, \%32.2'si (n=39) iki üç haftada bir fen eğitimine yer verdiklerini belirtmişlerdir. Bütün yaş gruplarında öğretmenlerin yüksek oranda haftada bir-iki kez fen eğitimi yaptıkları görülmektedir.

Tablo 3 'te çocukların yaş gruplarına göre öğretmenlerin fen etkinlikleri sirasında kullanıldığı yöntem ve tekniklerin dağılımı yer almaktadır.

Tablo 3. Çocukların yaş gruplarına göre öğretmenlerin fen etkinlikleri sırasında kullanıldı̆̆ı yöntem ve tekniklerin dă̆ılımı

\begin{tabular}{lcccccc}
\hline & \multicolumn{5}{c}{ Öğretmenin çalıştı̆̆ yaş grubu } \\
\cline { 2 - 8 } & $\mathbf{3 6 - 4 8}$ ay & \multicolumn{4}{c}{$\mathbf{4 8 - 6 0}$ ay } & $\mathbf{6 0 - 7 2}$ ay \\
\cline { 2 - 8 } & $\mathbf{n}$ & $\mathbf{0}$ & $\mathbf{n}$ & $\mathbf{\%}$ & $\mathbf{n}$ & $\mathbf{\%}$ \\
\hline Kavram haritası & 0 & 0 & 0 & 0 & 5 & 4.1 \\
\hline Analoji & 1 & 11.1 & 0 & 0 & 4 & 3.3 \\
\hline Problem çözme & 1 & 11.1 & 0 & 0 & 3 & 2.5 \\
\hline Çizim yaptırma & 0 & 0 & 2 & 10.5 & 4 & 3.3 \\
\hline Bilgi alışverişi ve tartışma & 0 & 0 & 1 & 5.3 & 10 & 8.3 \\
\hline Deney & 4 & 44.4 & 7 & 36.8 & 59 & 48.8 \\
\hline Proje çalışması & 0 & 0 & 2 & 10.5 & 6 & 5.0 \\
\hline İnceleme gezisi ve gözlem & 1 & 11.1 & 0 & 0 & 9 & 7.4 \\
\hline Düz anlatım & 1 & 11.1 & 7 & 36.8 & 11 & 9.1 \\
\hline Soru-cevap & 0 & 0 & 0 & 0 & 6 & 5.0 \\
\hline Drama & 1 & 11.1 & 0 & 0 & 4 & 3.3 \\
\hline Toplam & 9 & 100 & 19 & 100 & 121 & 100 \\
\hline
\end{tabular}


Tablo 3'te çocukların yaş gruplarına göre öğretmenlerin fen etkinlikleri sırasında kullanıldıkları yöntem ve tekniklerin dağılımı incelendiğinde, 3648 ve 60-72 aylık çocuklarla çalışan öğretmenlerin en çok deney; 48-60 aylık çocuklarla çalışan öğretmenlerin en çok deney ve düz anlatımı kullandıkları belirlenmiştir. Bir başka deyişle öğretmenlerin hangi yaş grubu ile çalışırsa çalışsın en çok deney ve düz anlatım yöntemini kullandıkları, farklı yöntem ve teknikleri uygulamadıkları söylenebilir.

Tablo 4. Çocuklarn yaş gruplarına göre öğretmenlerin dünya ve uzay bilimi ile ilgili içerik hakkındaki görüşleri ve bu içeriği kullanma durumlarına ilişkin dağılım

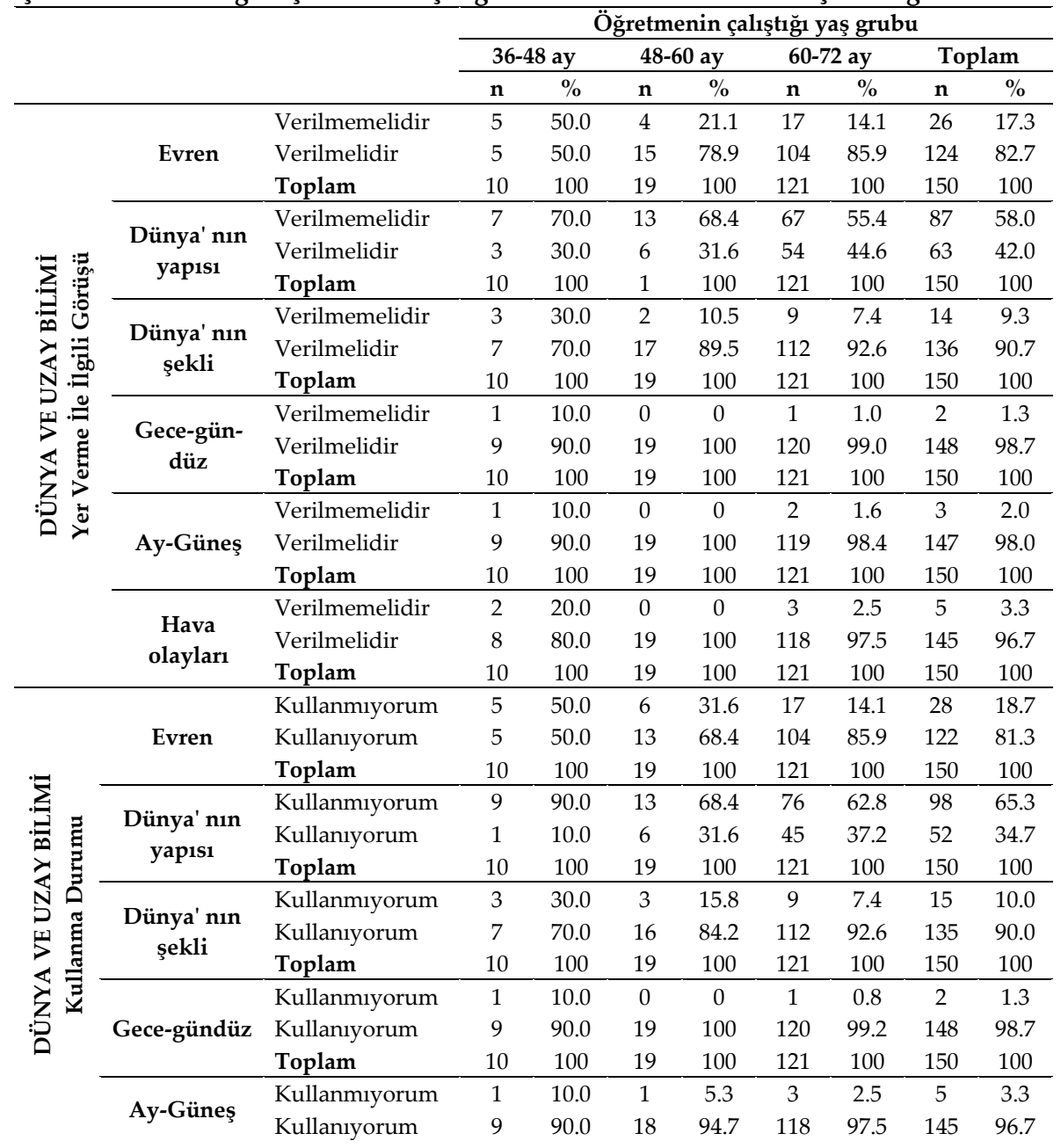




\begin{tabular}{llcccccccc} 
& Toplam & 10 & 100 & 19 & 100 & 121 & 100 & 150 & 100 \\
\hline \multirow{3}{*}{ Hava olayları } & Kullanmiyorum & 2 & 20.0 & 0 & 0 & 2 & 1.6 & 4 & 2.7 \\
& Kullaniyorum & 8 & 80.0 & 19 & 100 & 119 & 98.4 & 146 & 97.3 \\
& Toplam & 10 & 100 & 19 & 100 & 121 & 100 & 150 & 100 \\
\hline
\end{tabular}

Tablo 4'te çocukların yaş gruplarına göre öğretmenlerin dünya ve uzay bilimi ile ilgili içerik hakkındaki görüşleri ve bu içeriği kullanma durumlarına ilişkin dağılımı yer almaktadır.

Tablo 4'te incelendiğinde, çalıştıkları yaş gruplarına göre öğretmenlerin dünya ve uzay bilimiyle ilgili içeriğe yer vermelerine ve bunları kullanmalarına ilişkin görüşlerinde benzerlik olduğu görülmüştür. Dünya ve uzay bilimine ilişkin olarak çocukların yaşları büyüdükçe öğretmenlerin yer verme sıklığı ve kullanılan konu/kavramların sayısında da artış olduğu belirlenmiştir. Gerek öğretmenlerin fen eğitiminin içeriğine ilişkin görüşlerinde gerekse fen etkinliklerine yer verme sıklıklarında yaş göre benzerlikler söz konusudur. Öğretmenler; bütün yaş gruplarında en yüksek oranda gece-gündüz, aygüneş, hava olaylarına, en az oranda da dünyanın yapısı ve evren konu/kavramına yer verilmesi gerektiğini belirtmişlerdir.

Tablo 5'te çocukların yaş gruplarına göre öğretmenlerin yaşam bilimi ile ilgili içerik hakkındaki görüşleri ve bu içeriği kullanma durumlarına ilişkin dağılımı yer almaktadır.

Tablo 5 incelendiğinde çalıştıkları yaş gruplarına göre öğretmenlerin yaşam bilimiyle ilgili yer verilebilecek içerik hakkında görüşleri benzerlik göstermekle birlikte fen eğitiminde en çok canlı ve cansız varlıklar, canlıların farklı özellikleri, bitkiler, hayvanlar; en az oranda da kalıtıma ilişkin konu/kavramlara yer verilmesi gerektiğini belirtmişlerdir. Bununla birlikte yaşam bilimine ilişkin içeriğe yer verme oranının yaşla birlikte arttığı da görülmektedir. 
Tablo 5. Çocukların yaş gruplarına göre öğretmenlerin yaşam bilimi ile ilgili içerik hakkındaki görüşleri ve bu içeriği kullanma durumlarına ilişkin dă̆ılım

\begin{tabular}{|c|c|c|c|c|c|c|c|c|c|c|}
\hline & \multicolumn{8}{|c|}{ Öğretmenin çalıştığı yaş grubu } \\
\hline & & & \multicolumn{2}{|c|}{$36-48$ ay } & \multicolumn{2}{|c|}{$48-60$ ay } & \multicolumn{2}{|c|}{$60-72$ ay } & \multicolumn{2}{|c|}{ Toplam } \\
\hline & & & $\mathbf{n}$ & $\%$ & $\mathrm{n}$ & $\%$ & $\mathbf{n}$ & $\%$ & $\mathrm{n}$ & $\%$ \\
\hline \multirow{27}{*}{ 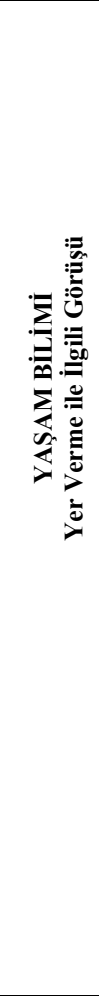 } & \multirow{3}{*}{$\begin{array}{l}\text { Canlı ve cansız } \\
\text { varlıkları }\end{array}$} & Verilmemelidir & 1 & 10.0 & 0 & 0 & 3 & 2.5 & 4 & 2.7 \\
\hline & & Verilmelidir & 9 & 90.0 & 19 & 100 & 118 & 97.5 & 146 & 97.3 \\
\hline & & Toplam & 10 & 100 & 19 & 100 & 121 & 100 & 150 & 100 \\
\hline & \multirow{3}{*}{$\begin{array}{c}\text { Canlıların ortak özel- } \\
\text { likleri }\end{array}$} & Verilmemelidir & 4 & 40.0 & 1 & 5.3 & 2 & 1.6 & 7 & 4.7 \\
\hline & & Verilmelidir & 6 & 60.0 & 18 & 94.7 & 119 & 98.4 & 143 & 95.3 \\
\hline & & Toplam & 10 & 100 & 19 & 100 & 121 & 100 & 150 & 100 \\
\hline & Canlıların & Verilmemelidir & 2 & 20.0 & 1 & 5.3 & 3 & 2.5 & 6 & 4.0 \\
\hline & \multirow{2}{*}{ farklı özellikleri } & Verilmelidir & 8 & 80.0 & 18 & 94.7 & 118 & 97.5 & 144 & 96.0 \\
\hline & & Toplam & 10 & 100 & 19 & 100 & 121 & 100 & 150 & 100 \\
\hline & \multirow{3}{*}{ Kalıtım } & Verilmemelidir & 6 & 60.0 & 10 & 52.6 & 54 & 44.6 & 70 & 46.7 \\
\hline & & Verilmelidir & 4 & 40.0 & 9 & 47.4 & 67 & 55.4 & 80 & 53.3 \\
\hline & & Toplam & 10 & 100 & 19 & 100 & 121 & 100 & 150 & 100 \\
\hline & \multirow{3}{*}{ Çevre sağlığı } & Verilmemelidir & 2 & 20.0 & 1 & 5.3 & 3 & 2.5 & 6 & 4.0 \\
\hline & & Verilmelidir & 8 & 80.0 & 18 & 94.7 & 118 & 97.5 & 144 & 96.0 \\
\hline & & Toplam & 10 & 100 & 19 & 100 & 121 & 100 & 150 & 100 \\
\hline & \multirow{3}{*}{ Bitkiler } & Verilmemelidir & 1 & 10.0 & 0 & 0 & 1 & 1.0 & 2 & 1.3 \\
\hline & & Verilmelidir & 9 & 90.0 & 19 & 100 & 120 & 99.0 & 148 & 98.7 \\
\hline & & Toplam & 10 & 100 & 19 & 100 & 121 & 100 & 150 & 100 \\
\hline & \multirow{3}{*}{ Hayvanlar } & Verilmemelidir & 2 & 20.0 & 0 & 0 & 1 & 1.0 & 3 & 2.0 \\
\hline & & Verilmelidir & 8 & 80.0 & 19 & 100 & 120 & 99.0 & 147 & 98.0 \\
\hline & & Toplam & 10 & 100 & 19 & 100 & 121 & 100 & 150 & 100 \\
\hline & \multirow{3}{*}{ Yaşam Döngüsü } & Verilmemelidir & 3 & 30.0 & 3 & 15.8 & 20 & 16.5 & 26 & 17.3 \\
\hline & & Verilmelidir & 7 & 70.0 & 16 & 84.2 & 101 & 83.5 & 124 & 82.7 \\
\hline & & Toplam & 10 & 100 & 19 & 100 & 121 & 100 & 150 & 100 \\
\hline & \multirow{3}{*}{ İnsan ve çevre } & Verilmemelidir & 1 & 10.0 & 0 & 0 & 4 & 3.3 & 5 & 3.3 \\
\hline & & Verilmelidir & 9 & 90.0 & 19 & 100 & 117 & 96.7 & 145 & 96.7 \\
\hline & & Toplam & 10 & 100 & 19 & 100 & 121 & 100 & 150 & 100 \\
\hline \multirow{15}{*}{ 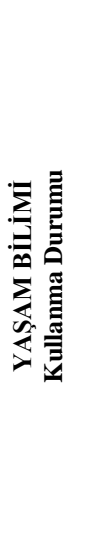 } & \multirow{3}{*}{$\begin{array}{l}\text { Canlı ve cansız } \\
\text { varlıkları }\end{array}$} & Kullanmıyorum & 1 & 10.0 & 1 & 5.3 & 3 & 2.5 & 5 & 3.3 \\
\hline & & Kullaniyorum & 9 & 90.0 & 18 & 94.7 & 118 & 97.5 & 145 & 96.7 \\
\hline & & Toplam & 10 & 100 & 19 & 100 & 121 & 100 & 150 & 100 \\
\hline & \multirow{3}{*}{$\begin{array}{c}\text { Canlıların ortak özel- } \\
\text { likleri }\end{array}$} & Kullanmiyorum & 4 & 40.0 & 3 & 15.8 & 2 & 1.7 & 9 & 6.0 \\
\hline & & Kullanıyorum & 6 & 60.0 & 16 & 84.2 & 119 & 98.3 & 141 & 94.0 \\
\hline & & Toplam & 10 & 100 & 19 & 100 & 121 & 100 & 150 & 100 \\
\hline & \multirow{3}{*}{$\begin{array}{l}\text { Canlıların farklı } \\
\text { özellikleri }\end{array}$} & Kullanmiyorum & 2 & 20.0 & 1 & 5.3 & 3 & 2.5 & 6 & 4.0 \\
\hline & & Kullanıyorum & 8 & 80.0 & 18 & 94.7 & 118 & 97.5 & 144 & 96.0 \\
\hline & & Toplam & 10 & 100 & 19 & 100 & 121 & 100 & 150 & 100 \\
\hline & \multirow{3}{*}{ Kalıtım } & Kullanmiyorum & $\begin{array}{llll}7 & & \end{array}$ & 70.0 & 11 & 57.9 & 61 & 50.4 & 79 & 52.7 \\
\hline & & Kullaniyorum & 3 & 30.0 & 8 & 42.1 & 60 & 49.6 & 71 & 47.3 \\
\hline & & Toplam & 10 & 100 & 19 & 100 & 121 & 100 & 150 & 100 \\
\hline & \multirow{3}{*}{ Çevre sağlığı } & Kullanmiyorum & 2 & 20.0 & 2 & 10.5 & 6 & 5.0 & 10 & 6.7 \\
\hline & & Kullanıyorum & 8 & 80.0 & 17 & 89.5 & 115 & 95.0 & 140 & 93.3 \\
\hline & & Toplam & 10 & 100 & 19 & 100 & 121 & 100 & 150 & 100 \\
\hline
\end{tabular}




\begin{tabular}{clcccccccc}
\hline \multirow{3}{*}{ Bitkiler } & Kullanmiyorum & 1 & 10.0 & 1 & 5.3 & 1 & 1.0 & 3 & 2.0 \\
& Kullaniyorum & 9 & 90.0 & 18 & 94.7 & 120 & 99.0 & 147 & 98.0 \\
& Toplam & 10 & 100 & 19 & 100 & 121 & 100 & 150 & 100 \\
\hline \multirow{3}{*}{ Hayvanlar } & Kullanmiyorum & 2 & 20.0 & 2 & 10.5 & 2 & 1.7 & 6 & 4.0 \\
& Kullaniyorum & 8 & 80.0 & 17 & 89.5 & 119 & 98.3 & 144 & 96.0 \\
& Toplam & 10 & 100 & 19 & 100 & 121 & 100 & 150 & 100 \\
\hline \multirow{3}{*}{ Yaşam Döngüsü } & Kullanmiyorum & 3 & 30.0 & 3 & 15.8 & 26 & 21.5 & 32 & 21.3 \\
& Kullaniyorum & 7 & 70.0 & 16 & 84.2 & 95 & 78.5 & 118 & 78.7 \\
& Toplam & 10 & 100 & 19 & 100 & 121 & 100 & 150 & 100 \\
\hline \multirow{3}{*}{ İnsan ve çevre } & Kullanmiyorum & 1 & 10.0 & 1 & 5.3 & 5 & 4.1 & 7 & 4.7 \\
& Kullaniyorum & 9 & 90.0 & 18 & 94.7 & 116 & 95.9 & 143 & 95.3 \\
& Toplam & 10 & 100 & 19 & 100 & 121 & 100 & 150 & 100 \\
\hline
\end{tabular}

Tablo 6'da çocukların yaş gruplarına göre öğretmenlerin fizik bilimi ile ilgili içerik hakkındaki görüşleri ve bu içeriği kullanma durumlarına ilişkin dağılımı yer almaktadır.

Tablo 6'dan elde edilen bulgular, çalıştıkları yaş grubuna göre öğretmenlerin fizik bilimiyle ilgili yer verilebilecek içerik hakkında görüşleri benzerlik göstermektedir. Çalıştıkları yaş grubuna göre fen eğitiminde yer verilebilecek fizik bilimi ile ilgili içeriğe dair görüşleri incelendiğinde, öğretmenlerin bütün yaş gruplarında en çok ses kavramına yer verilmesi gerektiğini belirttikleri görülmektedir.

Çalışılan yaş grubuna göre öğretmenlerin fizik bilimi ile ilgili konu/kavramları kullanma durumlarına bakıldığında 36-48 ay ve 48-60 aylık çocuklarla çalışan öğretmenlerin en fazla ses; 60-72 aylık çocuklarla çalışan öğretmenlerin en fazla ısı konu/kavramlarına yer verdikleri bulunmuştur. Bütün gruplar dikkate alındığında öğretmenlerin en düşük oranda hareket ve kuvvet konu/kavramlarına yer verdikleri belirlenmiştir. Çocukların yaşları ilerledikçe öğretmenlerin yer verilmesi gereken konu/kavramlara ilişkin görüşlerinde de belirgin bir olumlu ilerleme söz konusuyken, bu içeriği kullanma boyutuna gelindiğinde belirgin bir düşüş olduğu görülmektedir. 
Okul Öncesi Öğretmenlerinin Fen Eğitiminin İçeriği ve Standartlarına İlişkin Görüşlerinin İncelenmesi

Tablo 6. Çocukların yaş gruplarına göre öğretmenlerin fizik bilimi ile ilgili içerik hakkındaki görüşleri ve bu içeriği kullanma durumlarına ilişkin dă̆ılımı

\begin{tabular}{|c|c|c|c|c|c|c|c|c|c|c|c|}
\hline & & & \multicolumn{9}{|c|}{ Öğretmenin çalıştığı yaş grubu } \\
\hline & & & \multicolumn{2}{|c|}{$36-48$ ay } & \multicolumn{3}{|c|}{$48-60$ ay } & \multicolumn{2}{|c|}{$60-72$ ay } & \multicolumn{2}{|c|}{ Toplam } \\
\hline & & & $\mathbf{n}$ & $\%$ & $\mathbf{n}$ & $\%$ & & n & $\%$ & $\mathbf{n}$ & $\%$ \\
\hline \multirow{21}{*}{ 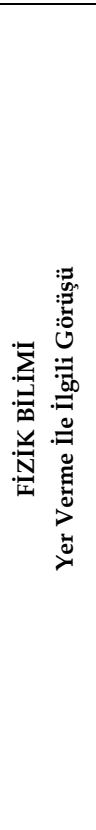 } & \multirow{3}{*}{ Madde } & Verilmemelidir & 5 & 50.0 & 9 & 47. & & 56 & 46.3 & 70 & 46.7 \\
\hline & & Verilmelidir & 5 & 50.0 & 10 & 52. & & 65 & 53.7 & 80 & 53.3 \\
\hline & & Toplam & 10 & 100 & 19 & 100 & & 121 & 100 & 150 & 100 \\
\hline & \multirow{3}{*}{$\begin{array}{c}\text { Hareket ve } \\
\text { Kuvvet }\end{array}$} & Verilmemelidir & 6 & 60.0 & 11 & 57. & & 68 & 56.2 & 85 & 56.7 \\
\hline & & Verilmelidir & 4 & 40.0 & 8 & 42 . & & 53 & 43.8 & 65 & 43.3 \\
\hline & & Toplam & 10 & 100 & 19 & 100 & & 121 & 100 & 150 & 100 \\
\hline & \multirow{3}{*}{ Isi } & Verilmemelidir & 5 & 50.0 & 4 & 21. & & 15 & 12.4 & 24 & 16.0 \\
\hline & & Verilmelidir & 5 & 50.0 & 15 & 78. & & 106 & 87.6 & 126 & 84.0 \\
\hline & & Toplam & 10 & 100 & 19 & 100 & & 121 & 100 & 150 & 100 \\
\hline & \multirow{3}{*}{ Işık } & Verilmemelidir & 4 & 40.0 & 5 & 26. & & 15 & 12.4 & 24 & 16.0 \\
\hline & & Verilmelidir & 6 & 60.0 & 14 & 73. & & 106 & 87.6 & 126 & 84.0 \\
\hline & & Toplam & 10 & 100 & 19 & 100 & & 121 & 100 & 150 & 100 \\
\hline & \multirow{3}{*}{ Ses } & Verilmemelidir & 2 & 20.0 & 2 & 10. & & 14 & 11.6 & 18 & 12.0 \\
\hline & & Verilmelidir & 8 & 80.0 & 17 & 89. & & 107 & 88.4 & 132 & 88.0 \\
\hline & & Toplam & 10 & 100 & 19 & 10 & & 121 & 100 & 150 & 100 \\
\hline & \multirow{3}{*}{ Enerji } & Verilmemelidir & 5 & 50.0 & 5 & 26. & & 27 & 22.3 & 37 & 24.7 \\
\hline & & Verilmelidir & 5 & 50.0 & 14 & 73. & & 94 & 77.7 & 113 & 75.3 \\
\hline & & Toplam & 10 & 100 & 19 & 100 & & 121 & 100 & 150 & 100 \\
\hline & \multirow{3}{*}{$\begin{array}{c}\text { Enerji kaynak- } \\
\text { ları }\end{array}$} & Verilmemelidir & 5 & 50.0 & 5 & 26. & & 20 & 16.5 & 30 & 20.0 \\
\hline & & Verilmelidir & 5 & 50.0 & 14 & 73. & & 101 & 83.5 & 120 & 80.0 \\
\hline & & Toplam & 10 & 100 & 19 & 100 & & 121 & 100 & 150 & 100 \\
\hline \multirow{21}{*}{ 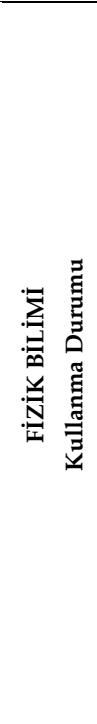 } & \multirow{3}{*}{ Madde } & Kullanmiyorum & 8 & 80.0 & & 10 & 52.6 & 60 & 49.6 & 78 & 52.0 \\
\hline & & Kullaniyorum & 2 & 20.0 & & 9 & 47.4 & 61 & 50.4 & 72 & 48.0 \\
\hline & & Toplam & 10 & 100 & & 19 & 100 & 121 & 100 & 150 & 100 \\
\hline & \multirow{3}{*}{$\begin{array}{c}\text { Hareket ve } \\
\text { Kuvvet }\end{array}$} & Kullanmiyorum & 9 & 90.0 & & 13 & 68.4 & 73 & 60.3 & 95 & 63.3 \\
\hline & & Kullanıyorum & 1 & 10.0 & & 6 & 31.6 & 48 & 39.7 & 55 & 36.7 \\
\hline & & Toplam & 10 & 100 & & 19 & 100 & 121 & 100 & 150 & 100 \\
\hline & \multirow{3}{*}{ Is1 } & Kullanmıyorum & 6 & 60.0 & & 6 & 31.6 & 16 & 13.2 & 28 & 18.7 \\
\hline & & Kullanıyorum & 4 & 40.0 & & 13 & 68.4 & 105 & 86.8 & 122 & 81.3 \\
\hline & & Toplam & 10 & 100 & & 19 & 100 & 121 & 100 & 150 & 100 \\
\hline & \multirow{3}{*}{ Işık } & Kullanmiyorum & 4 & 40.0 & & 6 & 31.6 & 18 & 14.9 & 28 & 18.7 \\
\hline & & Kullanıyorum & 6 & 60.0 & & 13 & 68.4 & 103 & 85.1 & 122 & 81.3 \\
\hline & & Toplam & 10 & 100 & & 19 & 100 & 121 & 100 & 150 & 100 \\
\hline & \multirow{3}{*}{ Ses } & Kullanmiyorum & 2 & 20.0 & & 3 & 15.8 & 17 & 14.1 & 22 & 14.7 \\
\hline & & Kullaniyorum & 8 & 80.0 & & 16 & 84.2 & 104 & 85.9 & 128 & 85.3 \\
\hline & & Toplam & 10 & 100 & & 19 & 100 & 121 & 100 & 150 & 100 \\
\hline & \multirow{3}{*}{ Enerji } & Kullanmiyorum & 7 & 70.0 & & 6 & 31.6 & 30 & 24.8 & 43 & 28.7 \\
\hline & & Kullaniyorum & 3 & 30.0 & & 13 & 68.4 & 91 & 75.2 & 107 & 71.3 \\
\hline & & Toplam & 10 & 100 & & 19 & 100 & 121 & 100 & 150 & 100 \\
\hline & \multirow{3}{*}{$\begin{array}{c}\text { Enerji } \\
\text { kaynakları }\end{array}$} & Kullanmiyorum & 6 & 60.0 & & 6 & 31.6 & 22 & 18.2 & 34 & 22.7 \\
\hline & & Kullanıyorum & 4 & 40.0 & & 13 & 68.4 & 99 & 81.8 & 116 & 77.3 \\
\hline & & Toplam & 10 & 100 & & 19 & 100 & 121 & 100 & 150 & 100 \\
\hline
\end{tabular}


Tablo 7. Çocukların yaş gruplarına göre öğretmenlerin bilimsel süreç becerileri hakkındaki görüşleri ve bu becerileri kullanma durumlarının dă̆ılımı

\begin{tabular}{|c|c|c|c|c|c|c|c|c|c|c|}
\hline & & & \multicolumn{8}{|c|}{ Öğretmenin çalıştığ1 yaş grubu } \\
\hline & & & \multicolumn{2}{|c|}{$36-48$ ay } & \multicolumn{2}{|c|}{$48-60$ ay } & \multicolumn{2}{|c|}{$60-72$ ay } & \multicolumn{2}{|c|}{ Toplam } \\
\hline & & & $\mathbf{n}$ & $\%$ & $\mathbf{n}$ & $\%$ & $\mathbf{n}$ & $\%$ & $\mathbf{n}$ & $\%$ \\
\hline \multirow{27}{*}{ 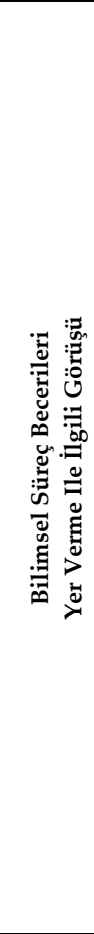 } & \multirow{3}{*}{ Gözlem yapma } & Verilmemelidir & 1 & 10.0 & 0 & 0 & 1 & 1.0 . & 2 & 1.3 \\
\hline & & Verilmelidir & 9 & 90.0 & 19 & 100 & 120 & 99.0 & 148 & 98.7 \\
\hline & & Toplam & 10 & 100 & 19 & 100 & 121 & 100 & 150 & 100 \\
\hline & \multirow{3}{*}{$\begin{array}{l}\text { Olay/Gözlemleri } \\
\text { betimleme }\end{array}$} & Verilmemelidir & 2 & 20.0 & 0 & 0 & 6 & 5.0 & 8 & 5.3 \\
\hline & & Verilmelidir & 8 & 80.0 & 19 & 100 & 115 & 95.0 & 142 & 94.7 \\
\hline & & Toplam & 10 & 100 & 19 & 100 & 121 & 100 & 150 & 100 \\
\hline & \multirow[t]{3}{*}{ Karşılaştırma } & Verilmemelidir & 3 & 30.0 & 0 & 0 & 2 & 1.7 & 5 & 3.3 \\
\hline & & Verilmelidir & 7 & 70.0 & 19 & 100 & 119 & 98.3 & 145 & 96.7 \\
\hline & & Toplam & 10 & 100 & 19 & 100 & 121 & 100 & 150 & 100 \\
\hline & \multirow{3}{*}{ Sinıflandırma } & Verilmemelidir & 3 & 30.0 & 0 & 0 & 1 & 1.0 & 4 & 2.7 \\
\hline & & Verilmelidir & 7 & 70.0 & 19 & 100 & 120 & 99.0 & 146 & 97.3 \\
\hline & & Toplam & 10 & 100 & 19 & 100 & 121 & 100 & 150 & 100 \\
\hline & \multirow{3}{*}{ Ölçme } & Verilmemelidir & 3 & 30.0 & 1 & 5.3 & 5 & 4.1 & 9 & 6.0 \\
\hline & & Verilmelidir & 7 & 70.0 & 18 & 94.7 & 116 & 95.9 & 141 & 94.0 \\
\hline & & Toplam & 10 & 100 & 19 & 100 & 121 & 100 & 150 & 100 \\
\hline & \multirow{3}{*}{ İletişim } & Verilmemelidir & 3 & 30.0 & 1 & 5.3 & 5 & 4.1 & 9 & 6.0 \\
\hline & & Verilmelidir & 7 & 70.0 & 18 & 94.7 & 116 & 95.9 & 141 & 94.0 \\
\hline & & Toplam & 10 & 100 & 19 & 100 & 121 & 100 & 150 & 100 \\
\hline & \multirow{3}{*}{ Sonuç Çıkarma } & Verilmemelidir & 3 & 30.0 & 1 & 5.3 & 3 & 2.5 & 7 & 4.7 \\
\hline & & Verilmelidir & 7 & 70.0 & 18 & 94.7 & 118 & 97.5 & 143 & 95.3 \\
\hline & & Toplam & 10 & 100 & 19 & 100 & 121 & 100 & 150 & 100 \\
\hline & \multirow{3}{*}{ Tahmin Etme } & Verilmemelidir & 2 & 20.0 & 1 & 5.3 & 2 & 1.7 & 5 & 3.3 \\
\hline & & Verilmelidir & 8 & 80.0 & 18 & 94.7 & 119 & 98.3 & 145 & 96.7 \\
\hline & & Toplam & 10 & 100 & 19 & 100 & 121 & 100 & 150 & 100 \\
\hline & & Verilmemelidir & 2 & 20.0 & 0 & 0 & 2 & 1.7 & 4 & 2.7 \\
\hline & & Verilmelidir & 8 & 80.0 & 19 & 100 & 119 & 98.3 & 146 & 97.3 \\
\hline & Deney yapma & Toplam & 10 & 100 & 19 & 100. & 121 & 100 & 150 & 100 \\
\hline \multirow{18}{*}{ 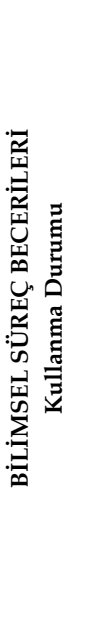 } & \multirow{3}{*}{ Gözlem yapma } & Kullanmiyorum & 1 & 10.0 & 1 & 5.3 & 2 & 1.6 & 4 & 2.7 \\
\hline & & Kullaniyorum & 9 & 90.0 & 18 & 94.7 & 119 & 98.4 & 146 & 97.3 \\
\hline & & Toplam & 10 & 100 & 19 & 100 & 121 & 100 & 150 & 100 \\
\hline & \multirow{3}{*}{$\begin{array}{l}\text { Olay/Gözlemleri } \\
\text { betimleme }\end{array}$} & Kullanmiyorum & 2 & 20.0 & 2 & 10.5 & 7 & 5.8 & 11 & 7.3 \\
\hline & & Kullaniyorum & 8 & 80.0 & 17 & 89.5 & 114 & 94.2 & 139 & 92.7 \\
\hline & & Toplam & 10 & 100 & 19 & 100 & 121 & 100 & 150 & 100 \\
\hline & \multirow{3}{*}{ Karşılaştırma } & Kullanmiyorum & 3 & 30.0 & 2 & 10.5 & 2 & 1.6 & 7 & 4.7 \\
\hline & & Kullaniyorum & 7 & 70.0 & 17 & 89.5 & 119 & 98.4 & 143 & 95.3 \\
\hline & & Toplam & 10 & 100 & 19 & 100 & 121 & 100 & 150 & 100 \\
\hline & \multirow{3}{*}{ Sinıflandırma } & Kullanmiyorum & 4 & 40.0 & 1 & 5.3 & 1 & 1.0 & 6 & 4.0 \\
\hline & & Kullaniyorum & 6 & 60.0 & 18 & 94.7 & 120 & 99.0 & 144 & 96.0 \\
\hline & & Toplam & 10 & 100 & 19 & 100 & 121 & 100 & 150 & 100 \\
\hline & \multirow{3}{*}{ Ölçme } & Kullanmiyorum & 4 & 40.0 & 1 & 5.3 & 8 & 6.6 & 13 & 8.7 \\
\hline & & Kullaniyorum & 6 & 60.0 & 18 & 94.7 & 113 & 93.4 & 137 & 91.3 \\
\hline & & Toplam & 10 & 100 & 19 & 100 & 121 & 100 & 150 & 100 \\
\hline & & Kullanmiyorum & 2 & 20.0 & 1 & 5.3 & 7 & 5.8 & 10 & 6.7 \\
\hline & İletişim & Kullanıyorum & 8 & 80.0 & 18 & 94.7 & 114 & 94.2 & 140 & 93.3 \\
\hline & & Toplam & 10 & 100 & 19 & 100 & 121 & 100 & 150 & 100 \\
\hline
\end{tabular}




\begin{tabular}{llcccccccc}
\hline \multirow{3}{*}{ Sonuç Çıkarma } & Kullanmıyorum & 3 & 30.0 & 2 & 10.5 & 5 & 4.1 & 10 & 6.7 \\
& Kullaniyorum & 7 & 70.0 & 17 & 89.5 & 116 & 95.9 & 140 & 93.3 \\
& Toplam & 10 & 100 & 19 & 100 & 121 & 100 & 150 & 100 \\
\hline \multirow{5}{*}{ Tahmin Etme } & Kullanmiyorum & 2 & 20.0 & 1 & 5.3 & 2 & 1.6 & 5 & 3.3 \\
& Kullaniyorum & 8 & 80.0 & 18 & 94.7 & 119 & 98.4 & 145 & 96.7 \\
& Toplam & 10 & 100 & 19 & 100 & 121 & 100 & 150 & 100 \\
\hline \multirow{3}{*}{ Deney yapma } & Kullanmiyorum & 3 & 30.0 & 1 & 5.3 & 4 & 3.3 & 8 & 5.3 \\
& Kullaniyorum & 7 & 70.0 & 18 & 94.7 & 117 & 96.7 & 142 & 94.7 \\
& Toplam & 10 & 100 & 19 & 100 & 121 & 100 & 150 & 100 \\
\hline
\end{tabular}

Tablo 7'de çocukların yaş gruplarına göre öğretmenlerin bilimsel süreç becerileri hakkındaki görüşleri ve bu becerileri kullanma durumlarının dağılımı yer almaktadır.

Tablo 7'de çocukların yaş gruplarına göre öğretmenlerin okul öncesi dönemde uygulanacak fen eğitiminde yer verilebilecek bilimsel süreç becerileri hakkındaki görüşleri ve bu becerileri kullanma durumları incelenmiştir. Öğretmenlerin bilimsel süreç becerilerine ilişkin görüşleri ile bu becerileri kullanma durumları arasında benzerlik olduğu görülmektedir. Öğretmenlerin büyük çoğunluğu $(\% 94 ; n>140)$ bilimsel süreç becerilerine fen eğitimi sırasinda yer verilmesi gerektiğini düşündükleri ve fen etkinliklerini uygularken de bu becerilere benzer düzeyde yer verdiklerini ifade ettikleri $(\% 91.3 ; n>136)$ belirlenmiştir. Ayrıca elde edilen bulgular doğrultusunda, öğretmenlerin çocukların yaşları büyüdükçe bilimsel süreç becerilerini kullanma konusundaki düşüncelerinde de olumlu yönde bir değişim olduğu görülmektedir.

Tablo 8'de eğitim sürecinde yapılması gereken fen eğitimi hakkında öğretmenlerin görüşlerinin dağılımı yer almaktadır.

Tablo 8. Ĕ̆itim sürecinde yapılması gereken fen eğitimi hakkında öğretmenlerin görüşlerinin dă̆ılımı

\begin{tabular}{|c|c|c|}
\hline \multicolumn{2}{|l|}{ Öğretmen görüşleri } & $\mathbf{n}$ \\
\hline \multicolumn{2}{|c|}{$\begin{array}{l}\text { Öğretim ilke ve yöntemlerine uygun olmalıdır. } \\
\text { (Çocukların özelliklerine göre, Basitten karmaşı̆̆a, Yaşama yakınlık, Somuttan } \\
\text { soyuta, Aktif katılım) }\end{array}$} & 212 \\
\hline \multicolumn{2}{|c|}{$\begin{array}{l}\text { Ortam uygun şekilde düzenlenmelidir. } \\
\text { (Fiziksel ortam/ Eğitsel ortam) }\end{array}$} & 36 \\
\hline \multirow{2}{*}{$\begin{array}{l}\text { Eğitim programına uygun şekilde } \\
\text { düzenlenmelidir. }\end{array}$} & Hazırlık (Amaç-kazanım, Kavram, Konu, Materyal) & 8 \\
\hline & $\begin{array}{l}\text { Uygulama (Yöntem- teknikler, Etkinlikler, } \\
\text { Etkinliklerin uygulanışı) }\end{array}$ & 132 \\
\hline
\end{tabular}




\begin{tabular}{lll}
\hline & $\begin{array}{l}\text { Değerlendirme (Dönüt, } \\
\text { Çocukların paylaşımları, Sorular) }\end{array}$ & 4 \\
\hline Toplam & & 392 \\
\hline
\end{tabular}

Öğretmenlerin yapılması geren fen eğitimiyle ilgili görüşlerine ilişkin toplamda 392 kod belirlenmiştir. Kodlar incelendiğinde, 212'sinin okul öncesi dönemde fen eğitiminin öğretim ilke ve yöntemlerine, 132'sinin eğitim programının uygulama basamağına, 36'sının eğitim ortamının uygun olarak yapılandırılmasına, 8 'inin eğitim programının hazırlık basamağına ve 4 'ünün eğitim programının değerlendirme basamağına ait kategoriler altında toplanması uygun bulunmuştur.

Tablo 9'da fen eğitimine ilişkin belirtilen konu ve kavramların standartlaştırılması konusunda öğretmenlerin görüş dağılımı yer almaktadır.

Tablo 9. Fen eğitimine ilişkin belirtilen konu ve kavramların standartlaştırılması konusunda öğretmenlerin görüş dă̆ılımı

\begin{tabular}{llll}
\hline & & $\mathbf{n}$ & $\mathbf{\%}$ \\
\hline & Evet & 116 & 78.9 \\
\cline { 2 - 4 } $\begin{array}{l}\text { Fen Eğitimine İlişkin Belirtilen Konu ve } \\
\text { Kavramların Standartlaştırılması Konusunda }\end{array}$ & Hayır & 11 & 7.5 \\
\cline { 2 - 4 } Öğretmenlerin Görüş Dağılımı & Kararsızım & 11 & 7.5 \\
\cline { 2 - 4 } & Cevapsız & 9 & 6.1 \\
\cline { 2 - 4 } & Toplam & $\mathbf{1 4 7}$ & $\mathbf{1 0 0 . 0}$ \\
\hline
\end{tabular}

Tablo 9'dan elde edilen bulgulara göre öğretmenlerin \%78.9'u fen eğitiminde standartların olması gerektiğini belirtmişlerdir. Bir başka deyişle, okul öncesi öğretmenlerinin yarısından fazlası fen eğitiminde standartların olmasinın önemli olduğunu düşünmektedir.

Tablo 10'da fen eğitimi konusunda standartların olmasının olumlu yönleri hakkında öğretmenlerin görüş dağılımı yer almaktadır.

Tablo 10 'da öğretmenlerin fen eğitiminde standartların olmasının olumlu yönleri hakkında toplamda 233 kod altında toplanan görüş belirttikleri görülmektedir. Bu kodlardan 100'ü öğretim ilke ve yöntemleri, 114'ü eğitim programının hazırlık, uygulama ve değerlendirme basamakları altında kategorize edilmiştir. 
Tablo 10. Fen eğitimi konusunda standartların olmasının olumlu yönleri hakkında öğretmenlerin görüş dă̆ılımı

\begin{tabular}{lll}
\hline & $\mathbf{n}$ & $\mathbf{\%}$ \\
\hline Öğretim ilke ve yöntemleri açısından olumlu yönleri olur. & 100 & 42.9 \\
(Çocukların özelliklerine göre, Basitten karmaşı̆̆a, Yaşama yakınlık, & & \\
Somuttan soyuta, Aktif katılım) & &
\end{tabular}

Ortam açısından olumlu yönleri olur.

19

8.2

( Fiziksel ortam (Eşitlik sağlar) /Eğitsel ortam

(Etkinlik çeşitliği, Eşit eğitim, Araştırma/merak duygusu)

\begin{tabular}{llll}
\hline $\begin{array}{l}\text { Eğitim programı açısından } \\
\text { olumlu yönleri olur. }\end{array}$ & $\begin{array}{l}\text { Hazırlık (İhtiyaca göre eğitim, } \\
\text { Öğretmene rehber olma) }\end{array}$ & 11 & 4.7 \\
\cline { 2 - 4 } & $\begin{array}{l}\text { Uygulama (Kolaylık, Düzen, } \\
\text { Bilimsel süreç becerileri, Yöntem-teknik) }\end{array}$ & 82 & 35.2 \\
\cline { 2 - 4 } & $\begin{array}{l}\text { Değerlendirme (Amaç kazanımlara } \\
\text { ulaşma, Ölçülebilir olma, Kalıcı } \\
\text { olma, Kaliteli olma, Verimli olma) }\end{array}$ & & \\
& & 21.0 \\
\hline Toplam & & & \\
\hline
\end{tabular}

Tablo 11'de fen eğitimi konusunda standartların olmasının olumsuz yönleri hakkında öğretmenlerin görüş dağılımı yer almaktadır.

Tablo 11'de öğretmenlerin fen eğitiminde standartlar olmasının olumsuz yönleri hakkında toplamda 132 kod altında görüş belirtmişlerdir. Kodlar incelendiğinde bu kodların 42' si eğitim programının uygulama basamağı, 23'ü eğitim ortamı, 21'i öğretim ilke ve yöntemleri ile ilişkilendirilerek kategorize edilmiştir. Ayrıca belirtilen 46 kod standartların olumsuz yönü olmayacağ 1 yönündedir.

Tablo 11. Fen Eğitimi Konusunda Standartların Olmasının Olumsuz Yönleri Hakkında Öğretmenlerin Görüş Dă̆ılımı

n $\%$

Öğretim ilke ve yöntemleri açısından olumsuz yönleri olur

(Seviyeye uygunluk, Basitten karmaşığa, Yaşama yakınlık,

Somuttan soyuta, Aktif katılım)

Ortam açısından olumsuz yönleri olur.

Fiziksel ortam (Maddi durumu olmayan çevreler, Malzeme yetersizliği)/ Eğitsel or- $23 \quad 17.4$

tam (Farklı yaş grubu içeren sınıflar, Bireysel farklılıklar, Sınıf ortamına uyum)

\begin{tabular}{llll}
\hline & Hazırlık (Kavramsal kısıtlama) & 3 & 2.3 \\
\cline { 2 - 4 } $\begin{array}{l}\text { Eğitim programı açısından } \\
\text { olumsuz yönleri olur }\end{array}$ & $\begin{array}{l}\text { Uygulama (Çocukları } \\
\text { kisıtlar, Bütünleştirilmiş etkinlikler, } \\
\text { Geleneksel eğitim) }\end{array}$ & 33 & 25.0 \\
\cline { 2 - 4 } & Değerlendirme (Uygulamadan sonra karar verilir) & 6 & 4.6 \\
\hline Herhangi bir olumsuzluk yaratmaz. & 46 & 34.8 \\
\hline \multicolumn{2}{l}{ Toplam } & 132 & 100 \\
\hline
\end{tabular}




\section{Tartışma ve Sonuç}

Bu çalışmada okul öncesi öğretmenlerinin fen eğitiminin içeriği ve standartlarına ilişkin görüşlerinin incelenmesi amaçlanmış ve elde edilen bulgular tartışılmıştır.

Araştırmada öğretmenlerin çalıştıkları yaş grubuna göre fen eğitimine yer verme sıklığ incelenmiş ve öğretmenlerin çalıştıkları yaş gruplarının fen eğitimine yer verme sıklığını etkilemediği (Tablo 2) ve genel olarak haftada bir ya da iki kez fen etkinliği uyguladıkları belirlenmiştir. Fen etkinlikleri okul öncesi dönemde çocukların keşfetmesi, problem çözmesi, yaratıc fikirler üretebilmesi için temel etkinliklerdendir (Alade, Lauricalle, Beaudoin-Ryan ve Wartella, 2016). Öğretmenlerin okul öncesi eğitimde çocukların gelişim özelliklerini dikkate alarak, çocukların yaşları büyüdükçe bununla paralel olarak uyguladıkları fen etkinliklerine dair nitelik ve niceliğin de artması beklenmektedir. Buna paralel olarak sınıfta yapılan etkinlikler çocukların yaşlarına göre farklılaşması ve çeşitlendirilmesi gerekmektedir. Çocukların yaş ve gelişim özelliklerine göre bireysel farklılıklarının da dikkate alınarak etkinliklerin planlanması ve uygulanması Okul Öncesi Eğitim Programı'nın temel özellik ve gerekliliklerinden biridir (MEB, 2013). Bu bağlamda araştırmada öğretmenlerin sınıflarında bulunan çocukların yaşlarına göre fen etkinliklerine yer verme sıklı̆̆ını ve içeriğini değiştirmemeleri ve sadece haftada 1-2 kez fen etkinliği yapmalarına ilişkin sonucun öğretmenlerin fen eğitimine ilişkin sınırlı bilgi ve materyale sahip olmasından kaynaklandığı düşünülebilir. Nitekim alanda öğretmenlerinin günlük planlarında fen etkinliklerine haftada birkaç kez yer verdiklerine dair araştırma sonuçları çalışmada elde edilen sonucu destekler niteliktedir (Sığırtmaç ve Özbek, 2011; Simsar, Doğan ve Yalçın, 2017; Yıldız ve Tükel, 2018).

Öğretmenlerin çalıştıkları yaş gruplarına göre fen etkinlikleri sırasında kullandıkları yöntem ve tekniklere bakıldığında, genel olarak en çok deney ve düz anlatım yöntem tekniklerini kullandıkları, farklı yöntem ve tekniklere fen eğitiminde çok fazla yer vermedikleri görülmektedir (Tablo 3). Okul öncesi dönem çocukların edindikleri fen deneyimlerinin gelecekteki fen başarısının güçlü bir yordayıcısı olduğu düşünüldügü̈nde çocukların yaşadıkları deneyimlerin önemi ortaya çıkmaktadır (Morgan, Farkas, Hillemeier ve Maczuga,2016). Okul öncesi fen eğitimi sürecinde, öğretmenlerin çocuklar için hazırladıkları planla birlikte dikkate alması gereken bir diğer nokta bu eğitimi 
çocuklar için nasıl anlamlı hale getirecekleridir (Ljung-Djärf, Magnusson ve Peterson, 2014). Okul öncesi dönem fen eğitimini çocuklar için anlamlı hale getirebilmek için çocukların yaş, gelişim özellikleri ve bireysel farklılıkları dikkate alınarak farklı yöntem tekniklere yer verilmesi gerekirken öğretmenlerin belli başlı birkaç yöntem/tekniği kullanmayı tercih ettikleri ortaya çımıştır. Bu sonucun; etkinliklerin daha çok öğretmen merkezli bir yaklaşımla uygulanması, öğretmenlerin bildikleri ve daha çok alışık oldukları yöntemleri kullanmaya istekli olmalarından kaynaklanabileceği düşünülebilir. Bu görüşü destekleyen alanda pek çok araştırma sonucu bulunmaktadır (Alkış Küçükaydın ve Uluçınar Sağır,2018; Ayvacı, Devecioğlu ve Yiğit, 2002; Gezgin ve Kılıç, 2015; Yıldız ve Tükel, 2018). Oysaki ulusal ve uluslararası düzeyde yapılan çalışmalarda kullanılan farklı yöntem ve tekniklerin çocukların öğrenmelerinde anlamlı farklılıklar yarattığı ortaya konmaktadır (Arıkan ve Kimzan, 2016; Brooks ve Wangmo, 2011; Günay Bilaloğlu, 2006; Hong ve Diamond, 2011; Katz, 2011; Öztürk Y1lmaztekin ve Tantekin Erden, 2017; Zhang, Parker, Eberhardt ve Passalaqua, 2011).

Araştırmada öğretmenlerin okul öncesi fen eğitiminde yer verilebilecek içeriklerden Dünya ve Uzay Bilimi, Yaşam Bilimi, Fizik Bilimi ile ilgili içeriğe yer verilmesi ve bunları kullanmalarına ilişkin görüşlerinde benzerlik olduğu sonucuna ulaşılmıştır. Yaş büyüdükçe öğretmenler tarafından yer verilmesi ve kullanılması uygun görülen içerik sayısında da artış olduğu belirlenmiştir. Öğretmenler Dünya ve Uzay Bilimi ile ilgili gece-gündüz, aygüneş, hava olaylarına ve en az oranda da dünyanın yapısı ve evren konu/kavramlarına yer verilmesi gerektiğini belirtirken, Yaşam Bilimi ile ilgili canlı ve cansız varlıklar, canlıların farklı özellikleri, bitkiler, hayvanlar ve kalıtım konu/kavramlarına; Fizik Bilimi ile ilgili ses, 1sı ve 1şık konu/kavramlara yer verilmesi gerektiğini vurgulamışlardır (Tablo 4, 5 ve 6). Ancak Fizik Bilimi ile ilgili içeriklere ilişkin öğretmenlerin görüşleri ve bu içerikleri kullanma durumları incelendiğinde öğretmenlerin okul öncesi dönem fen eğitiminde fizik bilimi ile ilgili içeriğe daha yüksek oranda yer verilmesi gerektiğini belirtirken bu içeriği kullanma durumlarının düştüğü görülmektedir. Diğer bir deyişle öğretmenler Fizik Bilimi ile ilgili içerikleri okul öncesi fen eğitiminde gerekli görürken bu içeriğe eğitim sürecinde daha az yer vermektedirler. 
Tablo 4, 5 ve 6 genel olarak incelendiğinde fen eğitimine ilişkin içeriğe yer verme oranlarının yaş arttıkça artması, çocukların yaşlarının öğretmenler tarafından planlanan fen eğitiminin içeriğinde dikkate alınan temel bir kriter olduğunu düşündürmüştür. Yaş grubu arttıkça öğretmenlerin fen eğitimine yer verme oranının artması, çocukların bir sonra yıl ilkokula başlayacak olmaları ve öğretmenlerin çocukları örgün eğitime hazırlama düşüncesi olarak değerlendirilebilir. Diğer yandan öğretmenlerin bazı içerikleri fen eğitiminde gereklilik olarak değerlendirirken uygulamada bu içeriklere yer verme oranlarının düşmesi, öğretmenlerin bazı fen eğitimi içeriklerine dair daha az bilgi ve deneyim sahibi olduklarını düşündürmüştür. Sonuç olarak çocukların yaşları dikkate alındığında fen eğitiminde öğretmenin içeriğe ilişkin çok fazla değişiklik yapmamasının; daha çok öğretmen merkezli yaklaşımı benimseyerek uygulamada daha iyi bildiği içerik alanına yönelik etkinlikler yapmayı tercih etmesinden kaynaklandığı söylenebilir.

$\mathrm{Bu}$ noktada alanda gerek eğitim programı ve standartlar geliştirmeye dönük olarak yapılan çalışmalar (Colorado Department of Education, 2009 Education Scotland, 2004; Michigan Department of Education, 2007; Ohio Department of Education, 2006; Pennsylvania Department of Education, 2009) gerekse fen kavramlarına yönelik yaşa dayalı yapılan çalışmalar sonucunda (Illhan, Tosun ve Xian-han Huang 2016; Saçkes, Flevares ve Trundle, 2010), özellikle yaşın program hazırlama ve standart geliştirmesinde belirleyici bir faktör olduğu ve buna paralel olarak içeriğin yaşla birlikte çeşitlendirmesi/farklılaştırılması gerektiği ortaya çıkmıştır. Bununla birlikte Leibham, Alexander ve Johnson'ın (2013) yaptığı çalışmada küçük çocukların ilgi alanları ve ilgi duydukları bilimsel kavramların çocukların fene dair ileriki başarılarında önemli bir etken olduğunun belirlenmesi, okul öncesi dönem için bir bilim eğitimi programının ya da eğitim standartlarının gerekliliğini göstermektedir.

Fen eğitiminde öğretmenlerin ele aldığı içerikle birlikte kullandıkları bilimsel süreç becerileri ve uygulama şekilleri de eğitimin önemli bir boyutudur. Araştırmadan elde edilen sonuçlar öğretmenlerin büyük çoğunluğunun bilimsel süreç becerilerine okul öncesi dönemde fen eğitimi sırasında yer verilmesi gerektiğini ve bu becerilere etkinlikler içerisinde yer verildiklerini göstermektedir. Bununla birlikte çocukların yaşları büyüdükçe öğretmenlerin bilimsel süreçleri kullandıklarına ilişkin görüşlerinde de bir artış olduğu görülmektedir (Tablo 7). 
Bilimsel süreç becerileri çocuğun kendi bilgisini oluştururken izlediği yoldur (Nikolaeva, 2008). Bireyin yaparak yaşayarak edindiği öğrenmelerin daha kalıcı olduğu düşünülürse erken yaşlarda bilimsel süreç becerilerine ilişkin uygulamalara yer verilmesi çocukların optimal gelişimleri açısından oldukça önemlidir. Bu bağlamda araştırmalar okul öncesi dönemde bilimsel süreç becerilerine yer verilerek yapılan eğitimlerle çocukların bilimi ve çevresini tanıyarak bilime karşı ilgilerinin arttığını; sebep-sonuç ilişkileri kurarak olayları anlamlandırmalarına kolaylık sağladığını, öğrenmenin daha kalıcı izli olmasını sağladığını ortaya çıkarmıştır (Nikolaeva, 2008; Şenyüz, 2008; Kula, Kanlı ve Tan, 2008). Bu sonuçlar ışığında araştırmada yer alan öğretmenlerin bilimsel süreç becerilerinin çocukların fen içeriklerini kazanmada önemli yere sahip olduğunun bilincinde olduklarını göstermektedir.

36-72 aylık çocuklar için yapılması gereken fen eğitimi hakkında öğretmenlerin görüşleri incelendiğinde; okul öncesi dönemde fen eğitiminin öğretim ilke ve yöntemlerine uygun olması, eğitim programının uygulama basamağına uygun şekilde yapılandırılması, eğitim ortamının uygun olarak düzenlenmesi, eğitim programının hazırlık ve değerlendirme basamağına uygun olması gerektiği üzerinde durdukları görülmektedir (Tablo 8). Buradan yola çıkılarak öğretmenlerin uygulamakta oldukları MEB 2013 Okul Öncesi Eğitim Programı'na yönelik teorik bilgiye sahip oldukları ve uygulamalarında programin temel felsefesinden ve ilkelerinden faydalandıkları ancak, programın genel yapısını bütünüyle özümseyemedikleri söylenebilir. $\mathrm{Bu}$ programda çocuğu merkeze alan bir yaklaşımla eğitim-öğretim faaliyetlerinin yürütülmesi üzerinde önemle durularak (MEB, 2013) bu faaliyetlerin çocuğa uygunluk, program ve eğitim ortamının düzenlenmesi aşamalarına dikkat edilerek yürütülmesi gerekmektedir. Elde edilen bulgulara benzer şekilde Akcanca, Aktemur Gürler ve Alkan (2017) yaptıkları çalışma sonucu öğretmenlerin fen eğitimi uygulamalarında çocukların yaş ve gelişim seviyelerine dikkat ettikleri, materyal seçiminin önemine vurgu yaptıkları ve fen uygulamalarının okul öncesi eğitim programına uygun, kavram öğretimini destekler nitelikte yapılması gerektiğini ifade ettikleri belirlenmiştir.

Öğrenme, günlük kavramların gelişimi olarak düşünüldüğünde günlük deneyimlerin, anlamlı fen deneyimlerine dönüşmesi ve etkinliklerin de bu bağlamda planlanması gerekmektedir (Abdo ve Carulla, 2019). Bu noktada çocukların ileriki yaşam becerilerine etki eden fen etkinlikleri konusunda 
öğretmenlerin bilgi, beceri, deneyim ve düşünceleri oldukça önem taşımaktadır. Fleer (2010), okul öncesi öğretmenlerinin fen eğitimini uygulamaya dönüştürürken zorlandıklarını belirtmektedir. Eğitim süreci planlanırken etkinliklerin öncelikle çocukların yaş ve gelişim özelliklerine uygun şekilde belirlenmesi, programa uygun şekilde planlanması, sınıf ortamı ve materyallerin buna göre düzenlenmesi ve etkinliğin değerlendirmesinin de bu kriter doğrultusunda yapılması gerekmektedir (MEB, 2013). Okul öncesi dönemde fen eğitimi standartlarını bu tür etkinlikler hazırlama ve uygulama konusunda öğretmenlere fen eğitimi öğretmenlere yol göstereceği düşünülmektedir.

Araştırmada okul öncesi dönemde fen eğitimi içerik standartlarına yer verilmesi konusundaki öğretmen görüşleri de incelenmiştir. Yapılan analizler sonucunda öğretmenlerin 3/4' ünden fazlası fen eğitiminde standartların olması yönünde görüş belirtmişlerdir (Tablo 9). Bu durumun öğretmenlerin fen eğitimine ilişkin güncel içerikler konusunda yeterli bilgi ve deneyime sahip olamamalarından ve bu konuda bir rehbere ihtiyaç duymalarından kaynaklandığı söylenebilir. Her yaş grubunda birçok farklı içerik alanına yönelik etkinlikler yapılabilir. Gözün Kahraman ve Ceylan'ın (2015) yaptıkları araştırma sonucunda çocukların bilim, yaşam, çevre, hava, su, enerji, değişim, insan vücudu, duyular, canlılık, böcekler vb. içerik alanlarında merak ve ilgilerinin olduğunu belirlemişlerdir. Çocukların yaş ve gelişim özelliklerine uygun ilgi ve meraklarını destekleyecek şekilde yapılacak uygun eğitimler çocukların bilimi anlama ve sevme düzeylerini olumlu etkileyecektir. Bununla birlikte çocukların yaşlarının öğrenmelerinde etkili olduğu ve bu durumun çocukların ilerideki başarılarını da etkilediği dikkate alınarak (Yeşilyurt, 2003); okul öncesi eğitim sürecinde fen eğitimine ilişkin standartların eğitim sürecinde eşitsizlikleri, farklılıkları ve yanlış uygulamaları en aza indireceği düşünülmektedir.

Her konuda olduğu gibi eğitimde de uygulanmakta olan programların olumlu ve olumsuz yönleri ortaya çıkabilmektedir. Okul öncesi dönemde fen eğitimi konusunda standartların olmasının olumlu yönlerine ilişkin öğretmenlerin görüşleri incelenmiştir (Tablo10). Yapılan içerik analizi sonucu öğretim ilke ve yöntemleri, eğitim programının hazırlık, uygulama ve değerlendirme basamağ 1 ve eğitim ortamı açısından standartların olumlu etkilerinin olacağı öğretmenler tarafından belirtilmiştir. Eğitimde standartların belirlenmesi, farklı yaş gruplarında çocuklara kazandırılması gereken 
beceri ve içeriklerin daha net ifade edilmesini sağlayacaktır. Üç yaşındaki bir çocukla beş yaşındaki bir çocuğun gelişim özellikleri ve öğrenme kapasiteleri birbiri ile aynı olmadığından hazırlanacak standartların öğretmenlere bu konuda rehberlik edeceği; adım adım eğitimin en alt basamağından en üst basamağına, çocukların neyi ne kadar bilmeleri gerektiği ve içeriklerin her birinde yer alan içeriğin kapsamının ve alt boyutlarının basitten zora doğru sıralanarak bir sonraki basamakta hangi düzeydeki alt becerilere yer vermesi gerektiği konusunda yol göstereceği ve bu sayede çocuklara sürekli aynı içeriklerin aynı düzeyde ele alındığı etkinlikler yapılmasını engelleyebileceği düşünülmektedir. Buna ilişkin olarak Morrison (2008), erken çocukluk eğitimi standartlarının çocukların bildikleri ve bildiklerinden yola çıkarak yapabilecekleri üzerine kurulması ve bu standartların yaş veya sınıf seviyesine uygun olarak belirlenmesi gerektiğini ifade etmiştir. Belirli bir fen eğitimi programına ve bu programda yer alacak içeriklere ilişkin standartların çocukların gelişimine de olumlu etki edeceği düşünülmektedir. Bu bağlamda Mantzicopoulos, Samarapungavan, Patrick (2009) çocukların gelişmekte olan bilimsel algılarını ortaya çıkarmak amacıyla bir eğitim programı hazırlamışlar ve normal anaokulu programına katılan ve ayrıca hazırlanan eğitim programına katılan çocuklar arasında karşılaştırmalar yapmışlardır. Sonuçta anlamlı bilim programlarıyla çocukların etkinliklerinde ayrı bir alan olarak fene yer verilmesinin; çocuklara dil, fenin içeriği ve süreç beceriyle ilgili olumlu gelişmeler yarattığı ortaya çıkmıştır. Buna paralel olarak Tao, Oliver ve Venville (2012) de yaptıkları araştırmada bilim programlarının çocukların kavramsal algılarında anlamlı farklılıklar yarattığını ve bilim programlarının fen eğitiminin önemli bir parçası olduğunu bulmuşlardır.

Araştırmada aynı zamanda okul öncesi fen eğitimi konusunda standartların olmasının olumsuz yönleri hakkında öğretmenlerin görüşleri içerik analizi kullanılarak incelenmiştir (Tablo 11). Analiz sonucunda öğretmenler eğitim programının hazırlık, uygulama ve değerlendirme basamağı, eğitim ortamı, öğretim ilke ve yöntemleri, açısından standartların olumsuz yönleri olacağını belirtmişlerdir. Özellikle farklı yaş gruplarının karma olarak bir arada bulunduğu sınıflarda, çocukların bireysel farklılıklarına ilişkin olarak uygulama sürecinde zorluklar yaşayabileceklerini ifade etmişlerdir. Bununla birlikte standartların olumsuz yönü olmayacağını belirten öğretmenler de mevcuttur. Öğretmenlerin fen eğitimi standartları konusunda 
bazı endişelerinin olduğu görülmektedir. Standartlar, her yerde aynı içerik ve hedeflerin ele alınarak, aynı etkinliklerin yapılması anlamına gelmez. Tersine çocukların yaş ve gelişim özellikleri, bireysel farklılıkları dikkate alınarak eğitim içeriklerinin ve eğitim sürecinin çerçevesinin belirlenmesini ve çocukların eğitim süreci sonunda potansiyelinin en üst noktaya çıkarılmasını sağlar. Böylelikle her eğitim kademesi sonunda çocukların yeterlilikleri daha net şekilde ortaya çıkacak ve yapılan uygulamalar tekrardan çok üzerine yeni içerikler eklenerek devam edebilecektir. Standartların, çocukların öğrenebileceği içeriklere dair öğretmenlere yol gösteren bir rehber olduğu düşünüldüğünde (Jalongo ve Isenberg, 2008: 54), elde edilen sonuç öğretmenlerin okul öncesi dönem fen eğitimine yönelik bir rehbere ihtiyaç duyduklarını göstermektedir.

\section{Öneriler}

Araştırmadan elde edilen sonuçlar okul öncesi öğretmenlerinin fen eğitimine ilişkin olarak standartlara, farklı içerik bilgisine, bilimsel süreç becerilerine ve farklı yöntem tekniklere yönelik yönlendirmelere gereksinimleri olduğunu göstermiştir. Ayrıca bu süreçte öğretmenlerin çalıştıkları yaş grubunun da bu içerikte dikkate alınması gerektiği ortaya çıkmışır. Ancak araştırma öğretmenlerin görüşleri, kullanılan görüşme formu, uygulamanın gerçekleştiği il ve okullar ile sınırlıdır. Bundan sonra yapılacak çalışmalarda öğretmenlerin planlamada kullandıkları dokümanların ve uygulamaları sırasında yapılan gözlemlerin veri toplama sürecine dahil edilmesi yararlı olacaktır. Öğretmenlere yönelik fen eğitiminde yer verilebilecek içerikleri içeren uygulamalı hizmet içi eğitimlerin verilmesi ve bu konuda öğretmenlere sağlanan kaynakların arttıılması konusunda çalışmaların yapılması yerinde olacaktır. Yapılan araştırmanın amacına yönelik yurt içinde okul öncesi dönem fen eğitimi içeriği ve içerik standartlarına dair kapsamlı bir araştırmanın yapılmadığı göz önünde bulundurulursa elde edilen sonuçlar doğrultusunda öğretmenlerin ihtiyaçları ve ortaya çıkan problemlerin en aza indirilmesi noktasında katkı sağlayacağı düşünülmektedir. 


\title{
EXTENDED ABSTRACT
}

\section{An Analysis of Preschool Teachers' Opinions on the Content and Standards of Science Education}

\author{
Hatice Dağlı - H. Elif Dağlığlu \\ Kahramanmaraş Sütcü Imam University, Gazi University
}

Preschool period is the period when children make sense of their environment effectively through their own experiences (Dickinson \& Porche, 2011). This period aims to enable children to structure their own knowledge, use scientific process skills and take an active role in social life by solving problems thanks to the appropriate content and curricula presented to them. One of the most basic activities that children can achieve these objectives is science activities that provide children with using scientific process skills and access information through their own experiences, just like a scientist. Children can observe, make predictions, and construct their knowledge by measuring and experimenting when necessary along with scientific contents during this process (Campbell and Jobling, 2012; Skamp, 2011). At that point, science education and its content used by pre-school teachers in the classes gain great significance. Thus, this study attempts to analyze teachers' views on the content of science education implemented in preschool education institutions and to identify the current situation in science education practices during preschool period.

The working group of the study consisted of 150 teachers working with 36-72 month-children in the kindergartens of primary schools and independent kindergartens affiliated to the Ministry of National Education and in the nursery classes affiliated to the Ministry of Family, Labor and Social Services located within Sivas city center. Having a qualitative research design, the study utilized a case study method. The study employed 'Teacher Views Interview Form on the Content of Science Education in Preschool Period' developed by the researchers. Before the form was prepared, the relevant national and international literature review was made; the content 
of science education during preschool period was examined, and the problem statement was determined, and the content that could be included in pre-school science education was identified by asking the views of 13 university lecturers who are experts in their field and who work at different universities. A pilot study was conducted with 26 pre-school teachers in order to analyze whether the items in the interview form are in harmony with the research questions. After testing that the research questions were clear, the form was made ready for implementation by making the necessary corrections. Content analysis was used during data analysis. Descriptive statistics were made, and frequency and percentage values of the items were calculated. As a result of the findings, teachers were found to state that day and night, moon-sun, weather events should be included within the subject of Earth and Space science at the highest rate in all age groups, while the world's structure and universe subject / concept at the lowest level. The teachers were identified to emphasize that living and inanimate beings, different characteristics of living things, plants, and animals should be mostly included in life science; whereas the subjects/concepts related to heredity should be included at the least rate.

Upon analyzing the views of the teachers regarding the science of physics, the teachers working with 36-48 month-children noted that the concept of sound should be mostly included within the content, while those working with 60-72 month-children stated that the heat subject/concepts should be mostly concerned. However, the least mentioned subject/concepts were determined to be motion and force. Besides, $78.9 \%$ of the teachers were identified to have positive views about the existence of science education standards, while $7.5 \%$ stated that there should not be standards. The teachers having positive views clarified that the content standards of science education in the curriculum will contribute to the planning of activities appropriate for the children's development and age as well as creating different learning experiences related to different contents. Those having negative views indicated that they may experience various problems in terms of the curriculum, implementation and the organization of the educational environment.

The research findings also suggested that teachers need a guide on preschool science education and different content knowledge, scientific process skills as well as different techniques. The research is limited to the teachers' 
views and the measurement tool. The studies conducted with different teachers related to preschool science education, observations to be made in the classroom, document reviews etc. are expected to be effective in gaining in-depth knowledge on this subject. Providing practical in-service trainings for teachers about the content of science education and increasing the resources will enrich the science education practices that teachers will perform in their classrooms.

\section{Kaynakça / References}

Abdo, K. ve Carulla, C.V. (2019). Designing play-based learning chemistry activities in the preschool environment, Chemistry Education Research and Practice, 20, 542-553.

Akcanca, N., Aktemur Gürler, S. ve Alkan, H. (2017). Okul öncesi öğretmenlerinin fen eğitimi uygulamalarına yönelik görüşlerinin belirlenmesi, Caucasian Journal of Science, 1-19.

Alabay, E. ve Yağan Güder, S. (2015). Hazır planlarda yer alan fen etkinliklerinin okul öncesi eğitim programı temel özellikleri açısından incelenmesi, Uluslar Arası Eğitim Bilimleri Dergisi,4,1-21

Alabay, E. (2010). Okul öncesi eğitimde fen programları. B. Akman, G. Uyanık Balat ve T. Güler (Ed.), Okul öncesi dönemde fen eğitimi içinde (s.63-86). Ankara: Pegem Akademi.

Ansberry, K.R. ve Morgan, E.R. (2007). More picture-perfect science lessons: using children's books to guide inquiry, K-4. USA: NSTA Press.

Alade, F., Lauricalle, A. R., Beaudoin-Ryan, L. ve Wartella, E. (2016). Measuring with Murray: Touchscreen technology and preschoolers' STEM learning. Computers in Human Behavior, 62, 433-441.

Alkış Küçükaydın, M., ve Uluçınar Sağır, Ş. (2018). Okul öncesi öğretmenliği öğretmen adaylarının fen öğretimine yönelik zihinsel imajları ve yöntem-teknik yaklaşımları. Hacettepe Üniversitesi Ĕ̆itim Fakültesi Dergisi, 33(4), 953-966. doi: 10.16986/HUJE.2018037332

Arıkan, A. ve Kimzan, İ. (2016). Okul öncesi eğitimde proje yaklaşımı: Ağaç Bilimcilerin Araştırmaları Projesi. Ilköğretim Online, 15(2), 498-528.

Ayvacı, H. Ş., Devecioğlu, Y. ve Yiğit, N. (2002). Okul öncesi öğretmenlerin fen ve doğa etkinliklerindeki yeterliliklerinin belirlenmesi. V. Ulusal Fen Bilimleri ve Matematik Ĕ̆itimi Kongresi'nde sunulmuş bildiri, ODTÜ, Ankara. 
Babaroğlu, A. ve Okur Metwalley, E. (2018). Erken çocukluk döneminde fen eğitimine ilişkin okulöncesi öğretmenlerinin görüşleri, Hitit Üniversitesi Sosyal Bilimler Enstitüsü Dergisi, 11(1), 125-148.

Brunton, P. ve Thornton, L. (2010). Science in the early years: building firm foundations from birth to five. UK: Sage Publications

Brooks, M., ve Wangmo, T. (2011). Introducing the project approach and use of visual representation to early childhood education in Bhutan. Early Childhood Research \& Practice, 13(1), 1-35.

Burke, L. A., and Hutchins, H. M. (2016). Training transfer: An integrative literature review. Human Resource Development Review 6 (3): 263-296.

Campbell, C. ve Jobling W. (2012). Science in early childhood. USA: Cambridge University Press.

Colorado Department of Education, (2009). Colorado Academic Standards. 21 Mayıs 2019 tarihinde http://www.cde.state.co.us/standardsandinstruction/index.asp sayfasından erişilmiştir.

Ceylan, Ş., Gözün Kahraman, Ö. ve Ülker, P. (2015). Çocukların meraklarına ilişkin annelerin ve öğretmenlerin düşünceleri: Bilim kavramı. Karabük Üniversitesi Sosyal Bilimler Dergisi, 5(1), 1-16.

Education Scotland, (2004). Curriculum for excellence. 20 Nisan 2019 tarihinde http://www.educationscotland.gov.uk/Images/all experiences outcomes tcm4-539562.pdf sayfasından erişilmiştir.

Dickinson, D.G. ve Porche, M.V. (2011). Relation between language experiences in preschool classroom $\mathrm{s}$ and children's kindergarten and fourth-grade language and reading abilities. Child Development, 1, 1-17.

Doğan, Y. ve Simsar, A. (2018). Preschool teachers' views on science education, the methods they use, science activities, and the problems they face, International Journal of Progressive Education, 14(5), 57-76.

Fleer, M. (2010), Early learning and development: cultural-historical concepts in play, New York: Cambridge University Press.

Genç Kumtepe, E. (2011). Okul öncesi eğitimde fen. A. Özdaş (Ed.), Okul öncesinde Fen Eğitimi içinde (s.132-158). Eskişehir: Anadolu Üniversitesi Açıköğretim Fakültesi Yayınları.

Gezgin, D. ve Kılıç, D. (2015). Okul öncesi öğretmenlerinin fen etkinliklerinde tercih ettikleri kazanım ve yöntemlerin belirlenmesi. Mersin Üniversitesi Ĕ̆itim Fakültesi Dergisi, 11(3), 620-630. 
Gözün Kahraman, Ö. ve Ülker, P. (2015). Bilimi yaratan duygu: Çocukların fen ve doğaya ilişkin konulardaki bilgi ve merakları. Türkiye Sosyal Araştırmalar Dergisi, 1, 207-230.

Gropen, J., Kook, J.F., Hoisington, C. ve Clark-Chiarelli, N. (2017). foundations of science literacy: Efficacy of a preschool professional development program in science on classroom instruction, teachers' pedagogical content knowledge, and children's observations and predictions. Early Education and Development, 28(5), 607-631.

Güler, D. ve Bıkmaz, F. (2002). Anasınıflarında fen etkinliklerinin gerçekleştirilmesine ilişkin öğretmen görüşleri. Eğitim Bilimleri ve Uygulamalart, 1(2), 249-267.

Günay Bilaloğlu, R. (2006). Altı yaş çocuklarına bağışıklık sisteminin analoji tekniğgiyle öğretiminin başar ve kahıılığa etkisi. Yüksek Lisans Tezi, Çukurova Üniversitesi Sosyal Bilimler Enstitüsü, Adana.

Günindi, Y. (2012). Türkiye'de okul öncesi eğitimi yaygınlaştırma çalı̧malarına bir bakış. IIB International Refereed Academic Social Sciences Journal, 5, 0-0.

Hatch, J.A. (2005). Teaching in the new kindergarten. Canada: Delmar Learning. Hong, S.Y. ve Diamond, K. E. (2011). Two Approaches to Teaching Young Children Science Concepts, Vocabulary and Scientific Problem- Solving Skill, Early Childhood Research Quarterly, 549, 1-11.

İlhan,N.,Tosun,C. ve Xian-han Huang, Y. (2016). Kindergarten students' levels of understanding some science concepts and scientific inquiry processes according to demographic variables: The sampling of Kilis Province in Turkey. Cogent Education, 3(1), 1-17.

İncikabı, L. ve Tuna, A.(2012). Türkiye ve Amerika eğitim sistemlerinin 60-72 aylıklar için geliştirilen okul öncesi matematik eğitimi programı açısından karşılaştırılması. Mersin Üniversitesi Eğitim Fakültesi Dergisi,8(3),94-101.

Jalongo, M. R. ve Isenberg, J. P. (2008). Exploring your role-an introduction to early childhood education. New Jersey: Pearson.

Johnston, J. (2005). Early explorations in science. England: Open University Press McGraw-Hill International.

Kallery, M. ve Psillos, D. (2002). What happens in the early years science classroom? The reality of teachers' curriculum implementation activities. European Early Childhood Education Research Journal, 10(2), 49-61.

Kandır, A., Özbey, S. ve İnal, G. (2010). Okul öncesi eğitimde program (1) kuramsal temeller. İstanbul: Morpa. 
Kandır, A., Can Yaşar, M., İnal, G., Yazıcı, E., Uyanık, Ö. ve Yazıcı, Z. (2012). Etkinliklerle bilim eğitimi. Ankara: Efil Yayınevi.

Katz, P. (2011). A Case study of the use of internet photobook teknology to enhange early childhood "scientists" identy. J Sci Educ. Technol, 20, 525-536.

Kula, G., Kanlı, U. ve Tan, M. (2010). 9., 10. ve 11. sınıf öğrencilerinin okul öncesi eğitim alma durumları ile bilimsel süreç becerileri arasındaki ilişki. IX. Ulusal Fen Bilimleri ve Matematik Eğitimi Kongresi(UFBMEK9) Dokuz Eylül Üniversitesi, İzmir. (Özet).

Leibham, M.B., Alexander, J.M. ve Johnson, K.E. (2013). Science interests in preschool boys and girls: relations to later self-concept and science achievement. Science Education, 97(4), 574-593.

Ljung-Djärf, A., A. Magnusson, A. ve S. Peterson, S. (2014). “From doing to learning: Changed focus during a pre-school learning study project on organic decomposition. International Journal of Science Education 36 (4), 659-676. doi: 10.1080/09500693.2013.822604

Mantzicopoulos, P., Samarapungavan, A. ve Patrick, H.(2009).We learn how to predict and be a scientist: early science experiences and kindergarten children's social meanings about science.Cognition and Instruction,27(4),312-369.

MEB, (2013). Okul öncesi ĕğitim programı. Ankara: MEB. http://education.state.mn.us/MDE/EdExc/StanCurri/index.html sayfasından erişilmiştir.

Michigan Department of Education, (2007). Science v.1.09. Kindergarten science grade level content expectations. Michigan Department of Education. 13 Nisan 2019 tarihinde http://www.michigan.gov/mde/0,4615,7-14028753---,00.html sayfasından erişilmiştir.

Morrison, G. S. (2008). Fundamentals of early childhood education. New Jersey: Pearson.

Morgan, P. L., Farkas, G., Hillemeier, M. M. ve Maczuga, S. (2016). Science achievement gaps begin very early, persist, and are largely explained by modifiable factors. Educational Researcher, 45(1), 18-35. doi:10.3102/0013189X16633182

Nikolaeva, S. N. (2008). The ecological education of preschool children. Russian Education, 50(3), 64-72.

National Research Council [NRC] (2012). A framework for K-12 science education: practices, crosscutting concepts and core ideas. Washington, D.C.: The National Academic Press 
NSES (1996). National science education standarts. National Academy Press: Washington. 25 Aralık 2012 tarihinde

http://www.nap.edu/openbook.php?record id=4962\&page=104 sayfasından erişilmiştir.

Ohio Department of Education, (2006). Ohio early learning content standards. 15 Haziran 2019 tarihinde http://www.ode.state.oh.us/GD/Templates/Pages/ODE/ODEDefaultPage.aspx?page=1 sayfasından erişilmiştir.

Olgan, R. (2015). Influences on Turkish early childhood teachers' science teaching practices and the science content covered in the early years. Early Child Development and Care, 185(6), 926-942.

Öçal, T. (2017). Türk okul öncesi eğitim programı ile ortak temel eyalet standartlarının matematik bağlamında karşılaştırılması, Eğitimde Nitel Araştırmalar Dergisi, 5(3), 155-171.

Ömeroğlu, E. ve Can Yaşar, M. (2004). Okul öncesi eğitim. Görüş Dergisi, 74-80.

Öztürk Yılmaztekin, E. ve Tantekin Erden, F. (2017) Investigating early childhood teachers' views on science teaching practices: the integration of science with visual art in early childhood settings.Early Child Development and Care, 187(7), 1194-1207, DOI: 10.1080/03004430.2016.1160899

Piasta, S. B., Pelatti C.Y. ve Miller, H.L. (2014). Mathematics and science learning opportunities in preschool classrooms. Early Education and Development, 25, 445-468.

Pennsylvania Department of Education, (2009). Pennsylvania learning standarts for early childhood. 14 Nisan 2019 tarihinde http://www.education.state.pa.us/portal/server.pt/community/pennsylvania department of education/7237 sayfasından erişilmiştir.

Saçkes, M., Flevare, L.M. ve Trundle K.C. (2010). Four- to six-year-old children's conceptions of the mechanism of rainfall. Early Childhood Research Quarterly, 25(4), 536-546.

Sarıtaş, R. (2010). Milli Eğitim Bakanlığı Okul Öncesi Eğitim Programına uyarlanmış GEMS (Great Explorations In Maths and Science) fen ve matematik programinın anaokuluna devam eden altı yaş grubu çocukların kavram edinimleri ve okula hazır bulunuşluk düzeyleri üzerindeki etkisinin incelenmesi. Yüksek Lisans Tezi, Gazi Üniversitesi Eğitim Bilimleri Enstitüsü, Ankara.

Skamp, K. (2011). Teaching primary science constructively.In K. Scamp (Ed.) Teaching primary science constructively (p. 1-54). USA: Cengage Learning. 
Arizona Department of Education. (2005). Standards based teaching and learning: science standard articulated by grade level kindergarten. 14 Ocak 2013 tarihinde http://www.azed.gov/standards-practices/ sayfasindan erişilmiştir.

Şenyüz, G. (2008). 2000 yıl fen bilgisi ve 2005 yıl fen ve teknoloji dersi öğretim programlarında yer alan bilimsel süreç becerileri kazanımlarının tespiti ve karşılaştırması. Yüksek Lisans Tezi, Gazi Üniversitesi, Ankara.

Sığırtmaç, A. ve Özbek, S. (2011). Okul öncesi öğretmenlerinin fen eğitimine ilişkin görüşleri ve uygulamalarının incelenmesi. e-Journal of New World Sciences Academy,6(1), 1039-1056.

Simsar, A., Doğan, Y. ve Yalçın, V. (2017). Okul öncesi sınıflarındaki fen merkezleri ve kullanım durumlarının incelenmesi- Kilis Örneği. Sosyal Bilimler Dergisi, 7(14), 147-164.

Tao, Y., Colette Oliver, M. ve Venville, G.J. (2012). Chinese and Australian year 3 children's conceptual understanding of science: A multiple comparative case study. International Journal of Science Education, 34(6), 879-901.

Taştepe, T. (2012). Erken çocukluk dönemi fen ve matematik eğitimi içerik standartları değerlendirme araçlarının geliştirilmesi. Yüksek Lisans Tezi, Gazi Üniversitesi Eğitim Bilimleri Enstitüsü, Ankara.

Tavşancıl, E. ve Aslan, A. E. (2001). Sözel, yazll ve diğer materyaller için içerik analizi ve uygulama örnekleri. İstanbul: Epsilon

$\mathrm{Tu}, \mathrm{T}$. ve Hsiao, W. (2008). Teacher-Child verbal interactions in preschool science teaching. Electronic Journal of Science Education,12(2), 1-23.

Uyanık Balat, G. (2010). Fen nedir ve çocuklar feni nasıl öğrenir?. B. Akman, G. Uyanık Balat ve T. Güler (Editörler), Okul öncesi dönemde fen eğitimi içinde (s. 1-17). Ankara: Pegem Akademi.

Ültay, N., Ültay, E., Çilingir, S. (2018). Okul öncesi öğretmenlerinin fen konularındaki uygulamalarının incelenmesi. Atatürk Üniversitesi Sosyal Bilimler Enstitüsü Dergisi ,773-792.

Yeşilyurt, S. (2003). Anasınıfı öğrencileri ve ilköğretim birinci sınıf öğrencilerinin canlı ve cansız kavramlarını anlama düzeyleri üzerine bir araştırma. Erzincan Eğitim Fakültesi Dergisi, 5(2), 83-96.

Yıldırım, C. (2008). Avrupa Birliği ülkelerinde Ve Türkiye'de okul öncesi eğitim. Electronic Journal of Social Sciences, 7(25), 91-110.

Yıldırım, A. ve Şimşek, H. (2013). Sosyal bilimlerde nitel araştırma yöntemleri. Ankara: Seçkin 
Yıldız S., ve Tükel, A. (2018). Okul öncesi öğretmenlerinin fen etkinliklerine yer verme durumlarının değerlendirilmesi. Uluslararası Sosyal Bilimler Ĕ̆itimi, 4(1), 49-59.

Yılmaz, N. (2010). Okul öncesi eğitimde fen deneyleri. Ankara: Eğiten Kitap.

Zhang, P., Parker, J. ve Eberhardt, J. (2011). What's so terrible about swallowing an apple seed? Problem-based learning in kindergarten. Journal of Science Education and Technology, 20(5), 468-481.

\section{Kaynakça Bilgisi / Citation Information}

Dağlı, H. ve Dağlıoğlu, H. E. (2020). Okul öncesi öğretmenlerinin fen eğitiminin içeriği ve standartlarına ilişkin görüşlerinin incelenmesi. OPUS-Uluslararası Toplum Araştırmaları Dergisi, 15(23), 1885-1919. DOI: 10.26466/opus.631378 